Review

\title{
Is There a Place for PD-1-PD-L Blockade in Acute Myeloid Leukemia?
}

\author{
Laura Jimbu ${ }^{1,2, *}$, Oana Mesaros ${ }^{1,2}$, Cristian Popescu ${ }^{1,3}$, Alexandra Neaga ${ }^{1}$, Iulia Berceanu ${ }^{2}$, Delia Dima ${ }^{2}$, \\ Mihaela Gaman ${ }^{4}$ and Mihnea Zdrenghea ${ }^{1,2}$ (D)
}

1 Department of Hematology, Iuliu Hatieganu University of Medicine and Pharmacy, 8 Babes Str., 400012 Cluj-Napoca, Romania; mesaros.oana@umfcluj.ro (O.M.); popescu.cristian@umfcluj.ro (C.P.); neaga.alexandra@umfcluj.ro (A.N.); mzdrenghea@umfcluj.ro (M.Z.)

2 Department of Hematology, Ion Chiricuta Oncology Institute, 34-36 Republicii Str., 400015 Cluj-Napoca, Romania; iuliaberceanu@yahoo.com (I.B.); deli_dima@yahoo.com (D.D.)

3 Department of Infectious Diseases, County Emergency Hospital Alba Iulia, 20 Decebal Str., 510093 Alba-Iulia, Romania

4 Department of Hematology, Carol Davila University of Medicine and Pharmacy, 050474 Bucharest, Romania; mihaela_dervesteanu@yahoo.com

* Correspondence: ioana.jimbu@umfcluj.ro; Tel.: +40-753-421-119

check for

updates

Citation: Jimbu, L.; Mesaros, O.; Popescu, C.; Neaga, A.; Berceanu, I.; Dima, D.; Gaman, M.; Zdrenghea, M. Is There a Place for PD-1-PD-L Blockade in Acute Myeloid Leukemia? Pharmaceuticals 2021, 14, 288. https://doi.org/10.3390/ ph14040288

Academic Editor: Eduardo Castañón Álvarez

Received: 31 January 2021

Accepted: 19 March 2021

Published: 24 March 2021

Publisher's Note: MDPI stays neutral with regard to jurisdictional claims in published maps and institutional affiliations.

Copyright: (c) 2021 by the authors. Licensee MDPI, Basel, Switzerland. This article is an open access article distributed under the terms and conditions of the Creative Commons Attribution (CC BY) license (https:/ / creativecommons.org/licenses/by/ $4.0 /)$.

\begin{abstract}
Checkpoint inhibitors were a major breakthrough in the field of oncology. In September 2014, based on the KEYNOTE-001 study, the Food and Drug Administration (FDA) approved pembrolizumab, a programmed cell death protein 1 (PD-1) inhibitor, for advanced or unresectable melanoma. Up until now, seven PD-1/PD-ligand(L)-1 inhibitors are approved in various solid cancers and hundreds of clinical studies are currently ongoing. In hematology, PD-1 inhibitors nivolumab and pembrolizumab were approved for the treatment of relapsed/refractory (R/R) classic Hodgkin lymphoma, and later pembrolizumab was approved for R/R primary mediastinal large B-cell lymphoma. In acute myeloid leukemia (AML), the combination of hypomethylating agents and PD-1/PD-L1 inhibitors has shown promising results, worth of further investigation, while other combinations or single agent therapy have disappointing results. On the other hand, rather than in first line, these therapies could be useful in the consolidation or maintenance setting, for achieving minimal residual disease negativity. Furthermore, an interesting application could be the use of PD-1/PD-L1 inhibitors in the post allogeneic hematopoietic stem cell transplantation relapse. There are several reasons why checkpoint inhibitors are not very effective in treating AML, including the characteristics of the disease (systemic, rapidly progressive, and high tumor burden disease), low mutational burden, and dysregulation of the immune system. We here review the results of PD-1/PD-L1 inhibition in AML and discuss their potential future in the management of this disease.
\end{abstract}

Keywords: acute myeloid leukemia; checkpoint inhibitors; immune system; cancer

\section{Introduction}

The immune system has a complex role in defending the host against infections, against the growth of tumor cells, and also in tissue repair [1]. When an antigen is identified by the adaptive immune system, the antigen-presenting cells (APCs) become active and migrate to the lymph nodes in order to activate B and T cells. For the activation of the $\mathrm{T}$ cells, two signals are needed. The first signal requires the interaction between the $\mathrm{T}$ cell receptor (TCR) situated on the T cells, and the epitope of the antigen, presented together with the MHC (major histocompatibility complex) molecules, situated on the APCs. The second, co-stimulatory, signal represents the interaction between CD28 (on the T cells) and B7.1 (CD80) and respectively B7.2 (CD86) (on the APCs) [2]. These two signals promote the proliferation, differentiation, and survival of T cells. In addition to the aforementioned co-stimulatory signaling, co-inhibitory signals also exist [3]. There are 
several molecules that control the response of the immune system and downregulate $\mathrm{T}$ cell activation, called immune checkpoints. The most investigated immune checkpoints are: cytotoxic T-lymphocyte-associated protein 4 (CTLA4) [4], programmed cell death protein 1 (PD-1) [5], T cell immunoglobulin-3 (TIM-3), lymphocyte activation gene-3 (LAG-3) [6], B and T lymphocyte attenuator (BTLA) [7], V-domain Ig suppressor of T cell activation (VISTA) [8], and T cell immunoglobulin and ITIM domain (TIGIT) [9]. Several studies revealed that tumor cells use these pathways to escape the immune system and to disseminate [10]. These discoveries led to the development of novel agents-checkpoint inhibitors, which "release the brakes" of the immune system.

\section{PD-1, PD-L1, and PD-L2 Biology}

PD-1, also called CD279, is a glycoprotein cell receptor which is part of the superfamily of B7-CD28 and it is encoded by a gene (pdcd-1) situated on chromosome 2 (2q37) [11]. Pdcd-1 consists of five exons [12]. Exon 1 encodes an extracellular peptide, exon 2 an immunoglobulin variable domain, exon 3 a transmembrane domain, and exons 4 and 5 encode an intracellular domain. PD-1 is a 50-55 kDA protein composed of 288 amino acids $[13,14]$.

PD-1 cDNA was first isolated in 1992 [15]. Its role in regulating the response of the immune system has been proved by PD-1 negative mouse models, which developed different autoimmune diseases [16,17]. Under physiological conditions, the PD-1-PDligand(L)1 pathway protects against autoimmunity, promoting apoptosis of effector T cells and stimulating the development of regulatory $\mathrm{T}$ cells (Tregs) from naïve $\mathrm{T}$ cells. Tregs are a subtype of $\mathrm{T}$ cells involved in maintaining peripheral tolerance, by downregulating effector T cells. They express CD4, CD25, and FOXP3 [18].

PD-1 is expressed on B cells, natural killer cell (NK cells), CD4+ T cells, CD8+ T cells, CD4- CD8- T cells, activated monocytes, dendritic cells (DC), macrophages, and immature Langerhans cells [11]. Its expression is enhanced by IL-2, IL-21, IL-15, IL-7, type 1 interferons (IFNs), IL-6, and IL-12 [11,19]. PD-1 has two known ligands: PD-L1 and PD-L2.

PD-L1 (called CD274 or B7-H1) was discovered in 1999 [20] and is a type I transmembrane protein, composed of 290 amino acids. It has $33 \mathrm{kDa}$ and it is composed of two extracellular domains (IgV- and IgC-like domains), one transmembrane and one intracellular domain. PD-L1 is encoded by the Cd274 gene on chromosome 9 (9p24) [12]. It is expressed on lymphoid tissue ( $\mathrm{T}$ cells, B cells, macrophages, and DC) and also on non-lymphoid structures (vascular endothelial cell, beta cells in the pancreas, placenta, and testicle) [11,21]. PD-L1 is expressed on cells infected by viruses such as Ebola virus, friend retrovirus, human immunodeficiency virus, herpes simplex virus type 1, hantavirus, influenza A virus, Japanese encephalitis virus, Kaposi's sarcoma-associated herpesvirus, lymphocytic choriomeningitis virus, respiratory syncytial virus, and varicella zoster virus [22]. Furthermore, PD-L1 is overexpressed in several types of cancers and hematological malignancies such as colorectal, ovarian, pancreatic, gastric, renal, breast, lung, thyroid, testicular cancer, melanoma, and Hodgkin lymphoma (HL) [23,24]. PD-L1 overexpression is upregulated by interferon gamma through the JAK-signal transducer and activator of transcription (STAT) pathway [25]. Other studies have shown PD-L1 overexpression in diffuse large B cell lymphoma (DLBCL), follicular lymphoma, peripheral T-cell lymphoma [26,27], multiple myeloma (MM) [28], chronic lymphocytic leukemia (CLL) [29], and acute myeloid leukemia (AML) [30].

PD-L2 (called CD273 or B7-DC) is also a type I transmembrane receptor, composed of 273 amino acids, and encoded by Pdcd1lg2 gene, situated on chromosome 9. It is expressed on macrophages, DC, and mast cells [12]. PD-L2 is associated with a higher production of T-cells and IFN gamma [31]. However, its role and mechanism of action is not completely understood. 


\section{PD-1 and PD-L1 Inhibitors in Cancer}

The advent of PD-1 and PD-L1 inhibitors was a major breakthrough in the treatment of several solid cancers. One of the first clinical studies, in 2010, showed the efficacy of MDX-1106 (nivolumab), a PD-1 inhibitor. Thirty-nine patients with refractory metastatic melanoma, renal cell carcinoma, non-small-cell lung cancer (NSCLC), prostate cancer, or colorectal cancer (CRC) were included in the study. Out of the 39 patients, one achieved complete remission (CR), and two partial remissions (PR) [32]. Later, pembrolizumab, a humanized monoclonal antibody which blocks the interaction between PD-1 and PD-L1, was approved in 2015 for unresectable or metastatic melanoma and in 2016 for metastatic NSCLC and head and neck squamous carcinoma (HNSCC) with progression on or after platinum-containing therapy. In October 2016, pembrolizumab received approval for the treatment of patients with metastatic NSCLC which express PD-L1, and who have progressed on or after platinum-containing treatment. In 2017, pembrolizumab was approved for the treatment of refractory classic HL (cHL) [33]. Later, the CkeckMate 227 trial showed better results (prolonged overall survival (OS), better response rate) in the treatment of NSCLC with the combination of nivolumab and ipilimumab (anti-CTLA-4 antibody) [34].

Atezolizumab is a humanized monoclonal antibody which targets PD-L1, and inhibits the interaction between PD-1 and its ligand [35]. Phase II and phase III trials showed efficacy of atezolizumab (MPDL3280A) in invasive bladder cancer [36], in platinum treated patients with locally advanced/metastatic urothelial carcinoma [37], in triple negative advanced/metastatic breast cancer [38], and in NSCLC [35].

Cemiplimab is a human monoclonal antibody targeting PD-1. Based on EMPOWERCSCC 1 trial, cemiplimab was approved by FDA in 2018 and by EMA in 2019, for the treatment of locally advanced/metastatic cutaneous squamous cell carcinoma not eligible for curative radiotherapy or surgery [39]. Several studies in other solid cancers and hematological malignancies are currently ongoing.

Durvalumab (MEDI4736) is a fully human monoclonal antibody targeting PD-L1 [40] which improved the OS of patients with advanced NSCLC [41], advanced urothelial bladder cancer [42], HNSCC progressed on platinum-based chemotherapy [43]. Several phase I and phase II studies showed efficacy in triple negative breast cancer [44] and in advanced-stage ovarian cancer in combination with tremelimumab [45] or olaparib [46]. Studies are ongoing.

Avelumab (MSB0010718C) is a fully human IgG1 anti-PD-L1 monoclonal antibody [47] which showed promising results in phase Ib clinical studies in patients with metastatic Merkel cell carcinoma [48], advanced unresectable mesothelioma [49], ovarian cancer [50], NSCLC [51], gastric or gastroesophageal junction cancer [52], refractory metastatic urothelial carcinoma [53], and renal cell carcinoma [54].

Spartalizumab (PDR001) is a humanized IgG4 anti PD-1 monoclonal antibody tested in various types of advanced or metastatic solid cancers [55,56]. A phase Ib open label study of spartalizumab and/or MBG453 and/or decitabine in patients with relapsed/refractory (R/R) AML or high-risk myelodysplastic syndrome (HR MDS) is currently recruiting [57].

Up until now, FDA approved PD-1 and PD-L1 checkpoint inhibitors for melanoma, renal cell carcinoma, head and neck cancer, urothelial carcinoma, CRC, hepatocellular carcinoma, small and non-small cell lung cancer, esophageal squamous cell carcinoma, cervical cancer, Merkel cell carcinoma, bladder cancer, certain types of endometrial carcinoma, and breast cancer. In hematologic malignancies PD-1, PD-L1 inhibitors are approved in HL and primary mediastinal large B-cell lymphoma (PMBCL).

Interestingly, a meta-analysis including 19 randomized clinical trials and 11,379 patients, showed that PD-1 inhibition leads to a higher OS and progression free survival (PFS) compared to PD-L1 inhibition (as single agent or in combination), in different types of cancers. While PD-1 inhibitors block the interaction between PD-1 and PD-L1 and, respectively, PD-L2, PD-L1 blockers inhibit only the PD-1/PD-L1 axis, allowing the tumor cells to escape the immune system via PD-1-PD-L2 axis and thus explaining the abovementioned results [58]. 
A high tumor mutational burden (TMB) can increase the diversity of tumor cell antigens, and will increase the chance that some of the antigens will be recognized by the immune system. It has been demonstrated that a high TMB is associated with a better response to PD-1 inhibition [59]. Moreover, as expected, a high expression of PD-L1 on tumor cells is associated with better response to checkpoint inhibitors [59].

\section{PD-1 and PD-L1 Inhibitors in AML}

\subsection{Introduction}

AML is a heterogenous disease characterized by the proliferation of abnormal myeloblasts in the bone marrow. AML has a dismal prognosis in young patients capable of withstanding high doses of chemotherapy and even worse in elderly, frail patients with comorbidities. Even though the understanding of AML pathogenesis has improved over the last decades, the standard treatment for AML patients dates back to 1973 [60]. The discovery of $\mathrm{t}(15 ; 17)$ and its personalized treatment, FLT3-inhibitors, BCL2-inhibitors, monoclonal antibodies, epigenetic regulators, and bispecific T-cell engager (BiTE) antibodies improved the OS of these patients [61]. The five year OS in young patients increased from $13 \%$ to $49 \%$ and in elderly patients from $8 \%$ to $13 \%$ from 1970 to 2015 [62]. Even so, there is an urgent need of novel, personalized drugs.

\subsection{Immune Checkpoint Blockade in AML-Why Was It Bound to Fail?}

Checkpoint inhibitors were a major breakthrough in the treatment of solid cancers, especially in those with high mutational burden due to the higher amount of neo-antigens [63]. This paradigm was later applied to hematological malignancies but with less success possibly due to different immune pathways and a higher immune tolerance [64]. However, as expected, in cHL, PD-1 inhibitors are of great benefit and demonstrated excellent results $[65,66]$.

Compared with cHL, AML has different characteristics. It is an aggressive, rapid progressive disease, which does not allow the immune system to develop a proper antileukemic response. A study in a murine model showed that localized implantation (subcutaneous) of leukemic cells triggers a response from the immune system, as opposed to a systemic (intravenous) route, which generates a tolerant state towards the malignant cells [67]. Moreover, the high tumor burden affects the response to PD-1 inhibitors [68]. Furthermore, AML has a low mutational burden and the newly formed antigens are expressed in different other tissues of the host [69]. Interestingly, some case series were reported, which describe spontaneous remissions in patients with AML, especially after an immune event (e.g., infections) suggesting the importance of the immune response [70]. Several studies suggested that Tregs are increased, both in peripheral blood and bone marrow of patients with AML, compared to healthy participants. However, there are conflicting results regarding the significance of increased Tregs [71]. Wang et al. demonstrated with their mouse model that the accumulation of Tregs in the leukemic microenvironment has a dismal prognosis. Interestingly, the destruction of Tregs in the tumor environment inhibits the anti-leukemic immune response. Thus, blocking the accumulation of Tregs in the tumor environment would be an attractive therapeutic approach. Wang et al. also demonstrated that a low number of Tregs increased survival and decreased leukemia burden [72]. Careful consideration must be given to the depletion of Tregs, which could lead to severe autoimmune events. Gutierrez et al. demonstrated in in vivo and in vitro studies that midostaurin, a FLT3 inhibitor, decreases Tregs in AML patients and healthy participants suggesting that a combination with immunotherapy could be possible and needs further investigation [73]. Other factors that promote tumor evasion and suppression are exhausted T cells, decreased function of $\mathrm{T}$ helper cells and production of cytokines and enzymes that suppress the immune system (e.g., indoleamine 2,3-deoxygenase 1, L-kynurenine, and 2-hydroxyglutarate) [71]. Another way to escape the immune system is for the AML cells to downregulate the MHC class II, a phenomenon especially seen in the post-transplantation setting [74]. 
In AML, the overexpression of CD47 inhibits phagocytosis via signal receptor proteinalfa (SIRP-alfa) on macrophages and DC and is associated with poor survival $[75,76]$. These discoveries led to the development of CD47 checkpoint inhibitors which are currently examined in several studies, for different types of cancer [77].

In conclusion, AML cells develop several mechanisms for hijacking the immune system via the immune checkpoints (Figure 1).

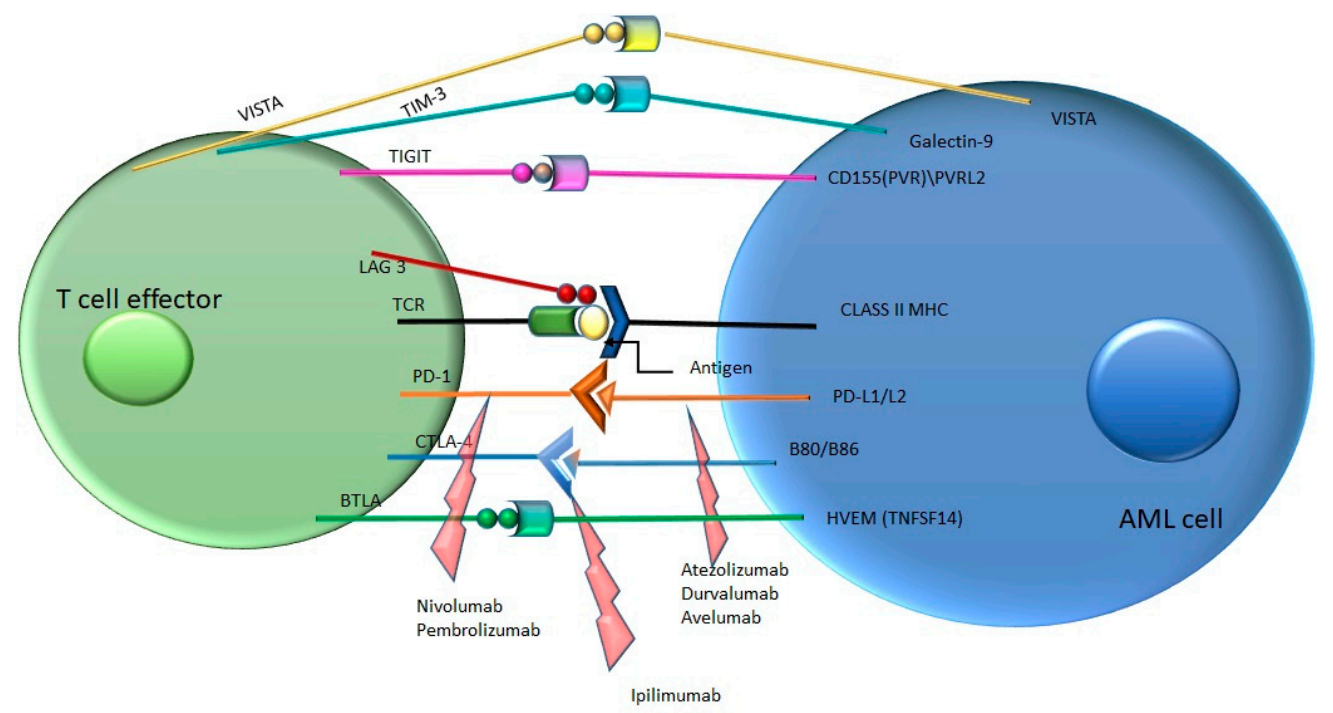

Figure 1. Immune checkpoint pathways and their inhibitors in acute myeloid leukemia (AML) (inhibitors-marked with red arrows). PVR-poliovirus receptor, PVRL2-poliovirus receptorrelated 2, HVEM-herpesvirus entry mediator.

\subsection{Immune Checkpoint Blockade in AML—Why Was It Bound to Succeed?}

A trial which included 124 bone marrow biopsies from patients with MDS, AML and chronic myelomonocytic leukemia (CMML) showed that PD-1, PD-L1, PD-L2 and CTLA4 were upregulated in CD34+ cells. AML and MDS bone marrow biopsies showed PD-1 positivity on the stroma and PD-L1 positivity on the blast population. Statistic correlations demonstrated that PD-1 expression is associated with increased age while PDL2 expression is associated with female gender [78]. While there are several clues that PD-1 and PD-L1 inhibitors would lack the success seen in solid cancers, some combinations are worth further investigations. PD-1 expression on T cell is regulated by DNA methylation. Apparently, hypomethylating agents (HMAs) are able to upregulate PD-1 expression on T cells, thus creating a resistance mechanism [79]. A clinical trial testing HMA and vorinostat showed that upregulated PD-L1 and PD-L2 leads to a lower median survival as compared to patients without upregulated PD-L1 and PD-L2 (6.6 months vs. 11.7 months) [80]. These conclusions led to the development of several clinical trials that tested the combination between a HMA and PD-1/PD-L1 blockers.

\subsection{Results in $A M L$}

Based on the Viale-A study, in USA, the standard of care for elderly patients with AML is now the combination of HMAs (azacitidine/decitabine) plus a BCL2 inhibitor (venetoclax). This combination improved OS (14.7 months vs. 9.6 months) and increased CR (36.7\% vs. 17.9\%) as compared with azacitidine alone [81]. Even with this combination elderly patients have a dismal prognosis. Thus, further investigation is needed. Currently, the combination of venetoclax + HMAs + pembrolizumab is evaluated to assess the percentage of patients who achieve undetectable minimal/measurable residual disease (MRD) compared to venetoclax + HMA (Blast MRD AML-2 study) [82].

PD-1, PD-L1 inhibitors are also studied in the R/R setting. A single arm, phase II clinical trial assessed the efficiency of azacitidine plus nivolumab in 70 elderly patients with 
R/R AML. The overall response (OR) was 33\% (15 CR/complete remission with incomplete hematological recovery (CRi), 1 partial remission (PR), 7 hematological improvement, $9 \%$ had stable disease (SD), and $58 \%$ no response). Overall response rate (ORR) to HMAs was better in naïve patients [83]. Another clinical trial, which enrolled 10 patients, tested the efficacy of pembrolizumab and decitabine in R/R AML. At the end of the eighth cycle, four patients presented SD, four progressed, one was MRD negative, and one was excluded from the study due to toxicity, during the fifth cycle. Median OS was 7 months with a median time of follow-up of 13 months [84].

Resistance to PD-1 inhibitors may be due to up-regulated CTLA-4 [85]. This observation led to studies that assessed the combination of HMA + PD-1 inhibitor + CTLA-4 inhibitor. Daver et al. showed in a phase II trial that azacitidine + nivolumab + ipilimumab improved OS compared to azacitidine + nivolumab and azacitidine alone $(10.5,6.4$, and 4.6 months, respectively) [83].

PD-1 inhibitors were also tested in combination with high dose chemotherapy. A single arm phase I-II clinical trial assessed nivolumab plus cytarabine and idarubicin in 44 patients with newly diagnosed AML or HR MDS. Median event free survival (EFS) was not reached at a median follow-up of 17.25 months. The median OS was 18.54 months [86]. Pembrolizumab was associated with high dose cytarabine in a clinical trial, which enrolled 37 patients with R/R AML. OR was 46\% and CR was 38\%. Nine patients received maintenance with pembrolizumab but seven of them relapsed [87].

There are several ongoing studies that investigate PD-1 inhibitors and MRD, and results are pending. Blast MRD AML-1 trial, which is currently ongoing, assesses the percentage of patients who achieve undetectable MRD with pembrolizumab in combination with intensive chemotherapy compared to chemotherapy alone. In a similar manner, the Blast MRD AML-2 trial assesses pembrolizumab in combination with azacitidine and venetoclax compared to azacitidine and venetoclax alone [88,89]. Moreover, nivolumab is tested as a single agent for eliminating MRD positivity in patients in complete remission [90]. Several authors consider PD-1/PD-L1 inhibitors a possible therapeutic approach in eliminating MRD positivity [68,91].

Allogenic hematopoietic stem cell transplantation (allo-HSCT) is an effective immunotherapy, for relapsed or high risk patients with AML, which uses the donor's immune cells to develop a response towards the disease (graft versus tumor effect). Patients who relapse after allo-HSCT have a poor prognosis. In these conditions, treatment is channeled towards harnessing the immune system either with a second HSCT, in selected cases, or with donor lymphocytes infusion (DLI) [92]. Another option, available in the future could be the PD-1/PD-L1 blockade. Several studies suggest that PD-1/PD-L1 blockers are capable of inducing graft versus leukemia effect (GVL) [2,93]. Interestingly, adding PD-L1 inhibitors early after allo-HSCT triggers GVL but with high graft versus host disease (GVHD) in comparison to adding them later in the course of the treatment which is associated with GVL with no GVHD [93]. Pembrolizumab was assessed in the setting of relapsed hematological malignancies following allo-HSCT. Eleven patients were included in the study, eight with AML, two with DLBCL, and one with HL. Of the seven patients evaluable, three patients progressed, two had SD, and two achieved CR [94]. The combination of nivolumab and ipilimumab is currently investigated in post allo-HSCT relapse in patients with AML and MDS [95]. A case series reported three AML patients treated with PD-1 inhibitors in the post allo-HSCT setting from which one achieved CR, one SD and one progressed [96]. PR was achieved with nivolumab in a heavily treated patient with HL, relapsed after allo-HSCT with the expense of gastrointestinal and hepatic GVHD [97]. Furthermore, another case series comprised of 31 patients, mostly HL cases, reported 77\% ORR with PD-1 inhibitors treatment in the aforementioned setting [98].

A meta-analysis of 24 articles evaluated the benefit of checkpoint inhibitors before or after allo-HSCT in different hematological malignancies and revealed that adding checkpoint blockers before or after allo-HSCT leads to higher rate of chronic, acute and hyperacute GVHD. T cells with low expression of PD-1 persist for 10 months or more 
leading to a higher risk of GVHD [99]. Several studies, especially in cHL, showed that PD-1 inhibitors are highly efficient in the relapsed setting, after allo-HSCT, at the cost of a higher rate of GVHD $[96,98,100]$. Thus, these agents could be used in relapsed AML but the risk GVHD flares should be thoughtfully considered [68]. On the other hand, Oran et al. demonstrated that the use of checkpoint inhibitors prior to allo-HSCT is feasible and post allo-HSCT administration of cyclophosphamide reduces the risk of acute GVHD [101].

After IFN-gamma exposure, PD-L1 expression had a minor increase in healthy patients but increased significantly in AML patients [102]. Several studies demonstrated that the expression of PD-L1 in AML blasts is restricted at diagnosis [102,103] and upregulated in relapse, progression, and CR [102]. The overexpression of PD-L1 in AML patients in CR is explained as a response of the malignant cells to chemotherapy (adaptive resistance) [102] A study from 2018, conducted on 55 patients, demonstrated that the incidence of PD-L1 expression is higher in patients with leukocytosis [30]. Other studies showed a correlation between TP53 mutation and the overexpression of PD-L1 [2,104].

A 36 patient study demonstrated that PD-L1 expression level is a negative prognostic factor in patients with FLT3- ITD (internal tandem duplications) and concomitant NPM1 mutation [105]. A small study published in 2018 showed that NPM1 mutated blasts showed a higher expression of PD-L1 when compared to NPM1wild type AML blasts [106].

A review of ongoing or completed clinical trials of PD-1, PD-L1 inhibitors in AML is presented in Table 1.

Table 1. Completed and ongoing clinical trials of programmed cell death protein 1 (PD-1), PD-ligand(L)1 inhibitors in AML.

\begin{tabular}{|c|c|c|c|c|}
\hline Disease Stage & Therapeutic Agents & Study Design & Participants & References \\
\hline $\begin{array}{l}\text { AML/HR MDS } \\
18-60 \text { years or }>60 \\
\text { eligible for intense } \\
\text { chemotherapy }\end{array}$ & $\begin{array}{c}\text { cytarabine } 1.5 \mathrm{~g} / \mathrm{m}^{2} \text { by } 24 \mathrm{~h} \text { continuous } \\
\text { infusion daily on days } 1-4 \text { ( } 3 \text { days in } \\
\text { patients }>60 \text { years) and idarubicin } \\
12 \mathrm{mg} / \mathrm{m}^{2} \text { daily on days } 1-3 . \text { nivolumab } \\
3 \mathrm{mg} / \mathrm{kg} \text {, day } 24 \text { every } 2 \text { weeks, } 1 \text { year } \\
\text { for responders }\end{array}$ & $\begin{array}{l}\text { Single-arm, phase II part } \\
\text { of the phase I/II study }\end{array}$ & $n=44$ & [86] \\
\hline R/R AML > 18 years & $\begin{array}{c}\text { azacitidine iv } / \mathrm{sc} 75 \mathrm{mg} / \mathrm{m}^{2} \text { days } 1-7+ \\
\text { nivolumab iv } 3 \mathrm{mg} / \mathrm{kg} \text { days } 1 \text { and } 14, \\
\text { every } 4 \text { to } 6 \text { weeks }\end{array}$ & $\begin{array}{l}\text { Non-randomized, } \\
\text { open-label, phase } \\
\text { II study }\end{array}$ & $n=70$ & [83] \\
\hline $\begin{array}{l}\text { Newly diagnosed } \\
\text { patients with TP53 } \\
\text { mutated AML }\end{array}$ & $\begin{array}{c}\text { Induction: nivolumab iv day } 15 \text { of cycle } \\
1 \text { and days } 1 \text { and } 15 \text { of subsequent cycles, } \\
\text { decitabine } 1-10 \text { of induction cycle } 1 \text { and } \\
\text { venetoclax orally daily on days } 1-21 \\
\text { Maintenance: nivolumab iv: days } 1 \text { and } \\
\text { 15, decitabine iv: days } 1-5 \text {, and venetoclax } \\
\text { po: days } 1-21\end{array}$ & $\begin{array}{l}\text { Non-randomized, } \\
\text { open-label, pilot study }\end{array}$ & $n=13$ & [107] \\
\hline $\begin{array}{l}\text { AML patients in first } \\
\text { CR/CRi after intense } \\
\text { chemotherapy not } \\
\text { candidates for HSCT }\end{array}$ & $\begin{array}{c}\text { nivolumab iv every } 2 \text { weeks for } 46 \text { cycles } \\
\text { vs. clinical observation }\end{array}$ & $\begin{array}{l}\text { Randomized, open-label, } \\
\text { phase II study }\end{array}$ & $n=82$ & [90] \\
\hline $\begin{array}{c}\text { AML/HR MDS } \\
\text { 18-60 years or }>60 \\
\text { eligible for intense } \\
\text { chemotherapy or R/R } \\
\text { AML/MDS for phase I }\end{array}$ & $\begin{array}{l}\text { Phase I: nivolumab iv } 1 \mathrm{mg} / \mathrm{kg} \text { on day } 24 \\
\text { of a } 28 \text { days cycle and after cycle } 2, \\
\text { nivolumab iv every } 2 \text { weeks, } 1 \text { year }+ \\
\text { idarubicin } 12 \mathrm{mg} / \mathrm{m}^{2} \mathrm{IV} \text { days } 1-3+ \\
\text { cytarabine iv } 1.5 \mathrm{~g} / \mathrm{m}^{2} \text { days } 1-4+ \\
\text { solumedrol } 50 \mathrm{mg} / \text { dexamethasone iv } \\
10 \mathrm{mg} \text { days with } 1-4 . \text { Phase II: nivolumab } \\
\text { maximum tolerated dose }\end{array}$ & $\begin{array}{l}\text { Non-randomized, open } \\
\text { label, phase I/II study }\end{array}$ & $n=75$ & [108] \\
\hline $\begin{array}{l}\mathrm{R} / \mathrm{R} \text { AML or MDS } \\
\text { patients following } \\
\text { allogenic HSCT }\end{array}$ & $\begin{array}{l}\text { nivolumab iv, days } 1 \text { and } 15 \text { vs. } \\
\text { ipilimumab iv day } 1 \text { vs. nivolumab iv, } \\
\text { days } 1,14 \text {, and } 28 \text { + ipilimumab iv, day } 1\end{array}$ & $\begin{array}{l}\text { Non-randomized, open } \\
\text { label, phase I study }\end{array}$ & $n=55$ & [95] \\
\hline
\end{tabular}


Table 1. Cont.

\begin{tabular}{|c|c|c|c|c|}
\hline Disease Stage & Therapeutic Agents & Study Design & Participants & References \\
\hline $\begin{array}{l}\text { AML } \\
\text { patients } \geq 55-85 \text { years, in } \\
\text { first/second CR, } \\
\text { suitable for } \\
\text { haploidentical } \\
\text { transplant }\end{array}$ & $\begin{array}{c}\text { cytarabine iv } 500-1000 \mathrm{mg} / \mathrm{m}^{2} \text { bid } \\
\text { days-2-4 + G-CSF, day } 0+\text { nivolumab } \\
40 \mathrm{mg} \text {, day } 5 \text { vs. cytarabine iv } \\
500-1000 \mathrm{mg} / \mathrm{m}^{2} \text { bid days } 1-3+ \\
\text { nivolumab } 40 \mathrm{mg} \text { day } 1\end{array}$ & $\begin{array}{l}\text { Randomized, open-label, } \\
\text { phase II study }\end{array}$ & $n=16$ & [109] \\
\hline $\begin{array}{c}\mathrm{R} / \mathrm{R} \\
\text { AML/biphenotypic } \\
\text { patients or newly } \\
\text { diagnosed } \geq 65 \text { years } \\
\text { AML patients, unfit for } \\
\text { in high dose } \\
\text { chemotherapy }\end{array}$ & $\begin{array}{c}\text { azacitidine iv /sc, days } 1-7 \text { or days } 1-4 \\
\text { and } 7-9+\text { nivolumab iv, days } 1 \text { and } 14 \\
\text { (cycle } 1-4 \text { ) and day } 1 \text { (cycle } 5 \text { and } \\
\text { subsequent) vs. same regimen }+ \\
\text { ipilimumab iv day } 1 \text { and then every } \\
6-12 \text { weeks }\end{array}$ & $\begin{array}{l}\text { Non-randomized, open } \\
\text { label, phase II study }\end{array}$ & $n=182$ & [110] \\
\hline $\begin{array}{c}\text { HR of relapse in AML } \\
\text { patients in } \\
\text { CR/CRi/CRp/PR }\end{array}$ & $\begin{array}{l}\text { nivolumab iv, days } 1 \text { and } 15 \text {. (cycles } 1-5 \text { ) } \\
\text { and nivolumab iv, day } 1 \text {, (cycle } 6-12) \text {, and } \\
\text { nivolumab iv, day } 1(\text { every } 3 \text { cycles starting } \\
\text { from cycle } 12 \text { ) or continue nivolumab } \\
\text { days } 1 \text { and } 15 \text { if progressive disease }\end{array}$ & $\begin{array}{l}\text { Non-randomized, open } \\
\text { label, phase II study }\end{array}$ & $n=30$ & [111] \\
\hline $\begin{array}{l}\text { R/R AML/HR-MDS, } \\
\text { IDH1 mutated }\end{array}$ & $\begin{array}{l}\text { ivosidenib PO } 500 \mathrm{mg} / \text { day }+ \text { nivolumab } \\
480 \mathrm{mg} \text { on day } 1 \text { cycle } 2 \text {. }\end{array}$ & $\begin{array}{l}\text { Non-randomized, open } \\
\text { label, phase II study }\end{array}$ & $n=45$ & [112] \\
\hline $\begin{array}{l}\text { 18-70 years AML/HR } \\
\text { MDS eligible for HSCT }\end{array}$ & $\begin{array}{c}\text { nivolumab iv }(1 \mathrm{mg} / \mathrm{kg} \text { or } 3 \mathrm{mg} / \mathrm{kg}) \text {, } \\
12 \text { doses, day } 1 \text { every } 3 \text { weeks, } 12 \text { cycles } \\
\text { vs. Ipilimumab }(0.3 \mathrm{mg} / \mathrm{kg} / 1.0 \\
\mathrm{mg} / \mathrm{kg} / 3.0 \mathrm{mg} / \mathrm{kg}) \text {, day } 1 \text {, every } 3 \text { weeks, } \\
6 \text { cycles vs. nivolumab iv }(3 \mathrm{mg} / \mathrm{kg}) \text {, } \\
12 \text { doses, day } 1 \text { every } 3 \text { weeks, } 12 \text { cycles + } \\
\text { ipilimumab }(0.3 \mathrm{mg} / \mathrm{kg} / 0.6 \mathrm{mg} / \mathrm{kg} / 1.0 \\
\mathrm{mg} / \mathrm{kg}) \text {, day } 1 \text {, every } 3 \text { weeks, } 6 \text { cycles }\end{array}$ & $\begin{array}{l}\text { Non-randomized, open } \\
\text { label, phase I study }\end{array}$ & $n=21$ & [113] \\
\hline $\begin{array}{l}\text { IPSS-1, IPSS- } 2 \text {, HR MDS, } \\
\text { low blast count AML }\end{array}$ & $\begin{array}{c}\text { DEC-205/NY-ESO-1 fusion protein } \\
\text { CDX-1401 intracutaneously + poly ICLC } \\
\text { sc, day-14 and day } 15 \text { (cycle } 1-4 \text { ), and day } \\
1 \text { of every } 4 \text { courses (cycle } 5 \text { and after) + } \\
\text { nivolumab iv days } 1 \text { and } 15 \text { and } \\
\text { decitabine iv, days } 1-5\end{array}$ & $\begin{array}{l}\text { Non-randomized, open } \\
\text { label, phase I study }\end{array}$ & $n=8$ & [114] \\
\hline
\end{tabular}

Recurrent

AML/ALL/CLL/CML BCR-

$\mathrm{ABL}+/ \mathrm{HL} / \mathrm{MM} /$ nonHodgkin Lym-

phoma/MDS/MPN/Other hematologic

malignancies after allo-HSCT

Induction: ipilimumab iv, day 1+ nivolumab iv, day 1 . (cycles of 21 days). Maintenance: ipilimumab iv every 12 weeks + nivolumab iv every 2 weeks in the absence of progressive disease or toxicity.
Non-randomized, open

label, phase I/IB study

$$
n=71
$$

nivolumab $3 \mathrm{mg} / \mathrm{kg}$ iv every 2 weeks for 6 months. After 6 months nivolumab was given every 4 weeks until 12 months on the study, and every 3 months until relapse
Non-randomized, open

label, phase II study

$n=8$

[116] not eligible for HSCT

flotetuzumab in step-up dose, followed by continuous infusion flotetuzumab, starting at week 2 of cycle 1 and

R/R AML who have exhausted standard of care options continuing through each 28-day cycle. MGA012 every two weeks.

\section{Non-randomized phase I study}


Table 1. Cont.

\begin{tabular}{|c|c|c|c|c|}
\hline Disease Stage & Therapeutic Agents & Study Design & Participants & References \\
\hline $\mathrm{R} / \mathrm{R}$ AML & $\begin{array}{l}\text { atezolizumab iv on day } 22 \text { of cycle } 1 \text { and } \\
\text { on days } 8 \text { and } 22 \text { on subsequent cycles }+ \\
\text { Hu5F9-G4 } 1 \mathrm{mg} / \mathrm{kg} \text { on days } 1 \text { and } 4, \\
15 \mathrm{mg} / \mathrm{kg} \text { on day } 8,30 \mathrm{mg} / \mathrm{kg} \text { on day } 11, \\
\text { and continue with } 30 \mathrm{mg} / \mathrm{kg} \text { every week }\end{array}$ & $\begin{array}{l}\text { Non randomized, } \\
\text { Open-label phase } \\
\text { Ib study }\end{array}$ & $n=21$ & [118] \\
\hline $\begin{array}{l}\mathrm{R} / \mathrm{R} \text { or newly diagnosed } \\
\text { patients with AML unfit } \\
\text { for intensive } \\
\text { chemotherapy }\end{array}$ & $\begin{array}{l}\text { atezolizumab } 840 \mathrm{mg} \text { iv on days } 8 \text { and } 22 \\
+ \text { guadecitabine } 60 \mathrm{mg} / \mathrm{m}^{2} \text { sc on Days } 1-5\end{array}$ & $\begin{array}{l}\text { Non randomized, } \\
\text { open-label phase } \\
\text { Ib study }\end{array}$ & $n=40$ & [119] \\
\hline $\begin{array}{l}\geq 60 \text { years AML patients } \\
\text { in CR/CRi, MRD+ not } \\
\text { eligible for HSCT }\end{array}$ & $\begin{array}{l}\text { BL-8040 SC } 1.25 \mathrm{mg} / \mathrm{kg} \text { days } 1-3 \text { of each } \\
\text { cycle + } \\
\text { atezolizumab } 1200 \mathrm{mg} \text { iv on Day } 2 \text { of } \\
\text { every cycle. }\end{array}$ & $\begin{array}{l}\text { Non-randomized, phase } \\
\text { Ib/II, Multicenter, single } \\
\text { arm, open-label study }\end{array}$ & $n=60$ & [120] \\
\hline $\begin{array}{l}\text { R/R AML patients } \\
\text { FLT3+ }\end{array}$ & $\begin{array}{l}\text { Phase I: establishing the right dose for } \\
\text { gilteritinib } \\
\text { Phase II: gilteritinib + atezolizumab }\end{array}$ & $\begin{array}{l}\text { Non-randomized, phase } \\
\text { I/II, open-label study }\end{array}$ & $n=61$ & [121] \\
\hline $\begin{array}{l}\text { Relapsed } \\
\text { AML/MDS/ALL after } \\
\text { allo-HSCT }\end{array}$ & pembrolizumab $200 \mathrm{mg}$ iv every 3 weeks & $\begin{array}{l}\text { Non-randomized, } \\
\text { open-label, phase IB } \\
\text { study }\end{array}$ & $n=20$ & [122] \\
\hline $\begin{array}{l}\text { Untreated AML, unfit } \\
\text { for intensive } \\
\text { chemotherapy }\end{array}$ & $\begin{array}{c}\text { decitabine } 20 \mathrm{mg} / \mathrm{m}^{2} \text { iv day } 1-5 \text {, every } \\
28 \text { days and avelumab was given at } \\
10 \mathrm{mg} / \mathrm{kg} \text { iv day } 1 \text {, every } 14 \text { days }\end{array}$ & $\begin{array}{l}\text { Non-randomized, single } \\
\text { arm, open label phase } \\
\text { I study }\end{array}$ & $n=7$ & [123] \\
\hline $\mathrm{R} / \mathrm{R} \mathrm{AML}$ & $\begin{array}{l}\text { azacitidine sc/iv days } 1-7 \text { or on days } 1-5 \\
\text { and } 8-9+\text { avelumab iv days } 1 \text { and } 14 \text { for } \\
4 \text { courses or until CR and on day } 1 \text { for } \\
\text { subsequent courses. }\end{array}$ & $\begin{array}{l}\text { Non-randomized, } \\
\text { open-label phase } \\
\text { Ib/II study }\end{array}$ & $n=19$ & [124] \\
\hline
\end{tabular}

\section{MDS patients $\geq 18$ years with IPSS-R}

intermediate, high, and very high or AML patients $\geq 65$ years ineligible for intense chemotherapy azacitidine $75 \mathrm{mg} / \mathrm{m}^{2} \mathrm{sc}$, days $1-7$ and durvalumab $1500 \mathrm{mg}$ iv on Day 1 every four weeks vs. azacitidine alone
Randomized, open-label, international, multicenter, phase $n=213$ II study
R/R AML pembrolizumab iv $200 \mathrm{mg}$, day 1 of every three-week cycle + decitabine $20 \mathrm{mg} / \mathrm{m}^{2}$, days 8-12 and 15-19
R/R AML patients and newly diagnosed elderly ( $\geq 65$ Years) AML patients

$\geq 60$ years AML patients
ineligible/refuse
intensive chemotherapy

azacitidine $75 \mathrm{mg} / \mathrm{m}^{2} \mathrm{iv} / \mathrm{sc}$ on days $1-7$ every 28 days + pembrolizumab $200 \mathrm{mg}$ iv every 3 weeks starting on day 8 of cycle 1
Single-arm open-label,

azacitadine iv / sc days 1-7 and venetoclax po days 1-28 of cycle 1 and days 21-28 vs. pembrolizumab iv day 8 cycle 1 and every 3 weeks in cycle $2-6+$ azacitadine iv / sc days $1-7+$ venetoclax po days $1-28$ of cycle 1 and days 21-28 of subsequent cycles.

$\geq 60$ years AML patients
in CR not eligible for
HSCT

pembrolizumab $200 \mathrm{mg}$ iv once every three weeks
Non-randomized, open-label, phase II trial phase I/II study

\section{Multicenter,} nonrandomized, open-label phase II study

$n=10$

Randomized phase II, open-label trial

$$
n=40
$$

(1)

Age-adjusted HiDAC followed by
pembrolizumab $200 \mathrm{mg}$ iv on day 14 in $\mathrm{R} / \mathrm{R}$ AML patients
Non-randomized, open-label, phase II trial $n=40$
18-70 years R/R AML patients 
Table 1. Cont.

\begin{tabular}{|c|c|c|c|c|}
\hline Disease Stage & Therapeutic Agents & Study Design & Participants & References \\
\hline $\begin{array}{l}\text { Newly-diagnosed } \\
\text { AML patients }\end{array}$ & $\begin{array}{l}\text { Induction phase: } 3+7+\text { pembrolizumab } \\
\text { (day } 8 \text { ) vs. } \\
3+7 \text {. Consolidation phase: HiDAC }+ \\
\text { pembrolizumab } \\
\text { vs. HiDAC. Maintenance phase: } \\
\text { pembrolizumab every } 3 \text { weeks for up to } \\
2 \text { years }\end{array}$ & $\begin{array}{l}\text { Randomized phase II, } \\
\text { open-label trial }\end{array}$ & $n=124$ & {$[89]$} \\
\hline $\begin{array}{l}\text { R/R AML patients or } \\
\text { newly diagnosed AML } \\
\text { patients not suitable for } \\
\text { high-dose } \\
\text { chemotherapy or HR } \\
\text { MDS or newly } \\
\text { diagnosed MDS }\end{array}$ & $\begin{array}{c}\text { AML: pembrolizumab iv days } 1 \text { and } 22 \\
\text { and decitabine iv days } 1-10 \text { MDS: } \\
\text { Pembrolizumab iv days } 1 \text { and } 22 \text { and } \\
\text { decitabine on days } 1-5 \text {. }\end{array}$ & $\begin{array}{c}\text { Non-randomized, } \\
\text { open-label, phase Ib trial }\end{array}$ & $n=54$ & {$[128]$} \\
\hline $\begin{array}{l}\text { NPM1 mutated AML } \\
\text { patients in CR or MRD } \\
\text { positivity or patients not } \\
\text { eligible for high-dose } \\
\text { chemotherapy or HSCT }\end{array}$ & $\begin{array}{l}\text { pembrolizumab } 200 \mathrm{mg} \text { iv + azacitidine } \\
75 \mathrm{mg} / \mathrm{m}^{2} \mathrm{sc}\end{array}$ & $\begin{array}{l}\text { Non-randomized, } \\
\text { open-label, phase II trial }\end{array}$ & $n=28$ & {$[129]$} \\
\hline $\begin{array}{c}\text { HR AML } \\
\text { (18-78 years) }\end{array}$ & $\begin{array}{l}\text { fludarabine }+ \text { melphalan }+ \text { Autologous } \\
\text { HSCT followed by pembrolizumab on } \\
\text { day }+1\end{array}$ & $\begin{array}{l}\text { Non-randomized, } \\
\text { open-label, phase II trial }\end{array}$ & $n=20$ & {$[130]$} \\
\hline $\begin{array}{l}\text { AML/MDS/cHL, B cell } \\
\text { NHL relapsed after } \\
\text { alloHSCT }\end{array}$ & pembrolizumab $200 \mathrm{mg}$ iv every 3 weeks & $\begin{array}{l}\text { Non-randomized, } \\
\text { open-label, phase I } \\
\text { pilot study }\end{array}$ & $n=26$ & {$[131]$} \\
\hline
\end{tabular}

RFS—Relapse Free Survival, MTD_Maximum Tolerated Dose, MRD-CR_minimal/measurable residual disease negativity and complete remission, ALL_-acute lymphoblastic leukemia, DOR_duration of response, DFS—Disease-Free Survival, bid-bis in die, CRp-complete response with incomplete platelet recovery, MPN—myeloproliferative neoplasm, CML-chronic myeloid leukemia, ADA-anti-drugantibodies, HiDAC-high dose Cytarabine.

\section{Toxicities}

Even though checkpoint inhibitors are not associated with the classic side effects of chemotherapy, they are not completely harmless, as they are associated with immunerelated adverse events (irAEs). These adverse events can vary from asymptomatic to life threating or rarely even death and they can affect almost every organ or system at any time of the treatment. Depending on the severity of the adverse events the treatment may vary from monitoring to high dose of corticosteroids [132]. Table 2 represents the most common adverse events following the treatment with PD-1/PD-L1 inhibitors.

Table 2. Adverse events after PD-1, PD-L1 blockade.

\begin{tabular}{|c|c|c|c|}
\hline Affected Organ/System & Adverse Event & Symptoms & References \\
\hline \multirow[t]{2}{*}{ Lung } & Pneumonitis & $\begin{array}{l}\text { asymptomatic, cough, dyspnea, chest } \\
\text { pain, wheezing }\end{array}$ & \multirow[t]{2}{*}[132,133]{} \\
\hline & Sarcoidosis & asymptomatic, cough, dyspnea & \\
\hline \multirow[t]{4}{*}{ Gastrointestinal } & Colitis & $\begin{array}{l}\text { diarrhea, bloody stools, abdominal } \\
\text { discomfort or pain, }\end{array}$ & \multirow{4}{*}[132,134]{} \\
\hline & Esophagitis & $\begin{array}{c}\text { anorexia, nausea } \\
\text { loss of appetite, abdominal pain, } \\
\text { nausea, vomiting }\end{array}$ & \\
\hline & Gastritis & & \\
\hline & Mucositis & & \\
\hline
\end{tabular}


Table 2. Cont

\begin{tabular}{|c|c|c|c|}
\hline Affected Organ/System & Adverse Event & Symptoms & References \\
\hline & Pancreatitis & $\begin{array}{c}\text { Fever, nausea, vomiting, abdominal pain with } \\
\text { irradiation in the back }\end{array}$ & {$[135]$} \\
\hline Liver & Hepatitis & asymptomatic, fever, nausea, vomiting & {$[134]$} \\
\hline \multirow[t]{3}{*}{ Skin } & Skin Rash & & \multirow{3}{*}[136]{} \\
\hline & Pruritus & & \\
\hline & Vitiligo & & \\
\hline \multirow[t]{4}{*}{ Endocrine } & Hypophysitis & $\begin{array}{l}\text { fatigue, headache, nausea, postural hypotension, } \\
\text { anorexia, tachycardia }\end{array}$ & {$[132,134]$} \\
\hline & Hypothyroidism & $\begin{array}{l}\text { asymptomatic, fatigue, constipation, } \\
\text { bradycardia, cold intolerance }\end{array}$ & \multirow[t]{2}{*}[132,137]{} \\
\hline & Hypertiroidism & tachycardia, tremor & \\
\hline & $\begin{array}{l}\text { Diabetes mellitus } \\
\text { type I }\end{array}$ & Asymptomatic, polyuria, polydipsia & {$[132,137]$} \\
\hline Ocular & Uveitis & eye redness and pain, decreased vision & {$[138]$} \\
\hline Neurologic & $\begin{array}{l}\text { Meningitis, encephalitis, Guillain Barre } \\
\text { syndrome, myastenia } \\
\text { gravis, polyradiculitis, }\end{array}$ & $\begin{array}{l}\text { nausea, fatigue, headache, blurred vision, } \\
\text { dysesthesia, fever, hallucinations, confusion, } \\
\text { muscle weakness, tetraplegia, paraplegia }\end{array}$ & {$[139]$} \\
\hline Cardiac & $\begin{array}{l}\text { Myocarditis, pericarditis } \\
\text { hypertension, arrhythmias, } \\
\text { myocardial infarction }\end{array}$ & palpitations, dyspnea, chest pain, fatigue & {$[134,140]$} \\
\hline Hematological & $\begin{array}{l}\text { Aplastic anemia, hemolytic anemia, } \\
\text { immune thrombocytopenia }\end{array}$ & fatigue, bleeding, infections & {$[132]$} \\
\hline Rheumatologic & $\begin{array}{l}\text { Vasculitis, Sicca syndrome, polymiositis, } \\
\text { systemic lupus erythematosus }\end{array}$ & $\begin{array}{c}\text { mialgia, joint swelling and pain, dryness of } \\
\text { mouth and eye }\end{array}$ & {$[141]$} \\
\hline
\end{tabular}

\section{Conclusions}

Checkpoint inhibitors were a major breakthrough in the treatment of solid cancers, and raised hope for a new, less aggressive therapy in hematological malignancies with suboptimal treatment results like AML. Despite promising results in some subtypes of lymphoma, currently being approved in HL and PMCBL, PD-1/PD-L1 checkpoint inhibitors have shown disappointing results in trials investigating their use as single agent, in both, de novo and relapsed AML. However, the combination of these agents with non- aggressive approaches, like HMAs, has shown promising activity in AML and is being currently studied in ongoing clinical trials. We believe that another potential use of PD-1/PD-L1 inhibitors in AML could be in the setting of either consolidation or maintenance where, in the presence of an at least partially restored immune system, they could promote MRD negativity. In this respect, they could be used either as single agents or in combinations. A very interesting therapeutic application, albeit of limited use, of checkpoint inhibitors in AML, could be in the post allo-HSCT setting, where, in the presence of AML relapse/progression, these agents might be useful in augmenting the immune reactivity of the graft, boosting the GVL effect, at the expense of also enhancing GVHD. To summarize, even though immune checkpoint blockade did not meet the high expectations they were credited with in AML, they are still a welcome addition to the limited therapeutic options in this group of diseases.

Author Contributions: Conceptualization, L.J., M.Z.; Resources, L.J.; Supervision, M.Z.; WritingOriginal Draft, L.J., O.M., A.N., C.P., D.D., M.G., I.B.; Writing-Review \& Editing L.J., M.Z. All authors have read and agreed to the published version of the manuscript.

Funding: This research received no external funding.

Institutional Review Board Statement: Not applicable.

Informed Consent Statement: Not applicable.

Data Availability Statement: Data sharing not applicable. 
Conflicts of Interest: The authors declare no conflict of interest.

\section{References}

1. Abul, K.; Abbas, A.H.L.; Shiv, P. Basic Immunology_Functions and Disorders of the Immune System, 5th ed.; Elsevier: Amsterdam, The Netherlands, 2016; Volume 1, p. 327.

2. Giannopoulos, K. Targeting Immune Signaling Checkpoints in Acute Myeloid Leukemia. J. Clin. Med. 2019, 8, 236. [CrossRef] [PubMed]

3. Chen, L. Co-inhibitory molecules of the B7-CD28 family in the control of T-cell immunity. Nat. Rev. Immunol. 2004, 4, 336-347. [CrossRef]

4. Rowshanravan, B.; Halliday, N.; Sansom, D.M. CTLA-4: A moving target in immunotherapy. Blood 2018, 131, 58-67. [CrossRef] [PubMed]

5. Mizuno, R.; Sugiura, D.; Shimizu, K.; Maruhashi, T.; Watada, M.; Okazaki, I.M.; Okazaki, T. PD-1 primarily targets TCR signal in the inhibition of functional T cell activation. Front. Immunol. 2019, 10, 630. [CrossRef] [PubMed]

6. Tu, L.; Guan, R.; Yang, H.; Zhou, Y.; Hong, W.; Ma, L.; Zhao, G.; Yu, M. Assessment of the expression of the immune checkpoint molecules PD-1, CTLA4, TIM-3 and LAG-3 across different cancers in relation to treatment response, tumor-infiltrating immune cells and survival. Int. J. Cancer 2019, 147, 423-439. [CrossRef]

7. De Sousa Linhares, A.; Leitner, J.; Grabmeier-Pfistershammer, K.; Steinberger, P. Not All Immune Checkpoints Are Created Equal. Front. Immunol. 2018, 9, 1909. [CrossRef]

8. Wang, L.; Rubinstein, R.; Lines, J.L.; Wasiuk, A.; Ahonen, C.; Guo, Y.; Lu, L.-F.; Gondek, D.; Wang, Y.; Fava, R.A.; et al. VISTA, a novel mouse Ig superfamily ligand that negatively regulates T cell responses. J. Exp. Med. 2011, 208, 577-592. [CrossRef]

9. Yu, X.; Harden, K.; Gonzalez, L.C.; Francesco, M.; Chiang, E.; Irving, B.; Tom, I.; Ivelja, S.; Refino, C.J.; Clark, H.; et al. The surface protein TIGIT suppresses T cell activation by promoting the generation of mature immunoregulatory dendritic cells. Nat. Immunol. 2009, 10, 48-57. [CrossRef]

10. Wu, X.; Gu, Z.; Chen, Y.; Chen, B.; Chen, W.; Weng, L.; Liu, X. Application of PD-1 Blockade in Cancer Immunotherapy. Comput. Struct. Biotechnol. J. 2019, 17, 661-674. [CrossRef]

11. Salmaninejad, A.; Valilou, S.F.; Shabgah, A.G.; Aslani, S.; Alimardani, M.; Pasdar, A.; Sahebkar, A. PD-1/PD-L1 pathway: Basic biology and role in cancer immunotherapy. J. Cell. Physiol. 2019, 234, 16824-16837. [CrossRef]

12. Akinleye, A.; Rasool, Z. Immune checkpoint inhibitors of PD-L1 as cancer therapeutics. J. Hematol. Oncol. 2019, 12, 1-13. [CrossRef]

13. Agata, Y.; Kawasaki, A.; Nishimura, H.; Ishida, Y.; Tsubata, T.; Yagita, H.; Honjo, T. Expression of the PD-1 antigen on the surface of stimulated mouse T and B lymphocytes. Int. Immunol. 1996, 8, 765-772. [CrossRef]

14. Boussiotis, V.A. Molecular and Biochemical Aspects of the PD-1 Checkpoint Pathway immune checkpoint blockade as cancer therapy. N. Engl. J. Med. 2017, 375, 1767-1778. [CrossRef]

15. Ishida, Y.; Agata, Y.; Shibahara, K.; Honjo, T. Induced expression of PD-1, a novel member of the immunoglobulin gene superfamily, upon programmed cell death. Embo J. 1992, 11, 3887-3895. [CrossRef]

16. Nishimura, H.; Minato, N.; Nakano, T.; Honjo, T. Immunological studies on PD-1-deficient mice: Implication of PD-1 as a negative regulator for B cell responses. Int. Immunol. 1998, 10, 1563-1572. [CrossRef]

17. Nishimura, H.; Okazaki, T.; Tanaka, Y.; Nakatani, K.; Hara, M.; Matsumori, A.; Sasayama, S.; Mizoguchi, A.; Hiai, H.; Minato, N.; et al. Autoimmune dilated cardiomyopathy in PD-1 receptor-deficient mice. Science 2001, 291, 319-322. [CrossRef]

18. Kondělková, K.; Vokurková, D.; Krejsek, J.; Borská, L.; Fiala, Z.; Ctirad, A. Regulatory T cells (TREG) and their roles in immune system with respect to immunopathological disorders. Acta Med. (Hradec Králové) 2010, 53, 73-77. [CrossRef]

19. Sunshine, J.; Taube, J.M. PD-1/PD-L1 inhibitors. Curr. Opin. Pharmacol. 2015, 23, 32-38. [CrossRef]

20. Dong, H.; Zhu, G.; Tamada, K.; Chen, L. B7-H1, a third member of the B7 family, co-stimulates T-cell proliferation and interleukin10 secretion. Nat. Med. 1999, 5, 1365-1369. [CrossRef]

21. Okazaki, T.; Honjo, T. The PD-1-PD-L pathway in immunological tolerance. Trends Immunol. 2006, 27, 195-201. [CrossRef]

22. Schönrich, G.; Raftery, M.J. The PD-1/PD-L1 axis and virus infections: A delicate balance. Front. Cell. Infect. Microbiol. 2019, 9, 207. [CrossRef]

23. Cha, J.H.; Chan, L.C.; Li, C.W.; Hsu, J.L.; Hung, M.C. Mechanisms Controlling PD-L1 Expression in Cancer. Mol. Cell 2019, 76, 359-370. [CrossRef]

24. Ilcus, C.; Bagacean, C.; Tempescul, A.; Popescu, C.; Parvu, A.; Cenariu, M.; Bocsan, C.; Zdrenghea, M. Immune checkpoint blockade: The role of PD-1-PD-L axis in lymphoid malignancies. Onco. Targets 2017, 10, 2349-2363. [CrossRef] [PubMed]

25. Mimura, K.; Teh, J.L.; Okayama, H.; Shiraishi, K.; Kua, L.F.; Koh, V.; Smoot, D.T.; Ashktorab, H.; Oike, T.; Suzuki, Y.; et al. PD-L1 expression is mainly regulated by interferon gamma associated with JAK-STAT pathway in gastric cancer. Cancer Sci. 2018, 109, 43-53. [CrossRef]

26. Andorsky, D.J.; Yamada, R.E.; Said, J.; Pinkus, G.S.; Betting, D.J.; Timmerman, J.M. Programmed death ligand 1 is expressed by non-Hodgkin lymphomas and inhibits the activity of tumor-associated T cells. Clin. Cancer Res. 2011, 17, 4232-4244. [CrossRef]

27. Li, Y.; Wang, J.; Li, C.; Ke, X.Y. Contribution of PD-L1 to oncogenesis of lymphoma and its RNAi-based targeting therapy. Leuk. Lymphoma 2012, 53, 2015-2023. [CrossRef] [PubMed] 
28. Yousef, S.; Marvin, J.; Steinbach, M.; Langemo, A.; Kovacsovics, T.; Binder, M.; Kröger, N.; Luetkens, T.; Atanackovic, D. Immunomodulatory molecule PD-L1 is expressed on malignant plasma cells and myeloma-propagating pre-plasma cells in the bone marrow of multiple myeloma patients. Blood Cancer J. 2015, 5, e285. [CrossRef] [PubMed]

29. Lewinsky, H.; Barak, A.F.; Huber, V.; Kramer, M.P.; Radomir, L.; Sever, L.; Orr, I.; Mirkin, V.; Dezorella, N.; Shapiro, M.; et al. CD84 regulates PD-1/PD-L1 expression and function in chronic lymphocytic leukemia. J. Clin. Investig. 2018, 128, 5479-5488. [CrossRef] [PubMed]

30. Brodská, B.; Fuchs, O.; Otevřelová, P.; Salek, C.; Kuželová, K. PD-L1 Is Frequently Expressed in Acute Myeloid Leukemia Patients with Leukocytosis. Blood 2016, 128, 5229. [CrossRef]

31. Zdrenghea, M.T.; Johnston, S.L. Role of PD-L1/PD-1 in the immune response to respiratory viral infections. Microbes Infect. 2012, 14, 495-499. [CrossRef] [PubMed]

32. Brahmer, J.R.; Drake, C.G.; Wollner, I.; Powderly, J.D.; Picus, J.; Sharfman, W.H.; Stankevich, E.; Pons, A.; Salay, T.M.; McMiller, T.L.; et al. Phase I study of single-agent anti-programmed death-1 (MDX-1106) in refractory solid tumors: Safety, clinical activity, pharmacodynamics, and immunologic correlates. J. Clin. Oncol. 2010, 28, 3167-3175. [CrossRef] [PubMed]

33. Keynote, P. Pembrolizumab KEYNOTE-001: An adaptive study leading to accelerated approval for two indications and a companion diagnostic. Ann. Oncol. 2017, 28, 1388-1398. [CrossRef]

34. Hellmann, M.D.; Paz Ares, L.; Bernabe Caro, R.; Zurawski, B.; Kim, S.W.; Carcereny Costa, E.; Park, K.; Alexandru, A.; Lupinacci, L.; De La Mora Jimenez, E.; et al. Nivolumab plus ipilimumab in advanced non-small-cell lung cancer. N. Engl. J. Med. 2019, 381, 2020-2031. [CrossRef] [PubMed]

35. Spigel, D.R.; Chaft, J.E.; Gettinger, S.; Chao, B.H.; Dirix, L.; Schmid, P.; Chow, L.Q.M.; Hicks, R.J.; Leon, L.; Fredrickson, J.; et al. FIR: Efficacy, Safety, and Biomarker Analysis of a Phase II Open-Label Study of Atezolizumab in PD-L1-Selected Patients With NSCLC. J. Thorac. Oncol. 2018, 13, 1733-1742. [CrossRef]

36. Castellano, D.; Duran, I.; Rodríguez-Vida, A.; Crabb, S.J.; van der Heijden, M.S.; Font Pous, A.; Gravis, G.; Anido Herranz, U.; Protheroe, A.; Ravaud, A.; et al. A phase II study investigating the safety and efficacy of neoadjuvent atezolizumab in muscle invasive bladder cancer (ABACUS). Ann. Oncol. Off. J. Eur. Soc. Med. Oncol. 2018, 29, viii319. [CrossRef]

37. Necchi, A.; Joseph, R.W.; Loriot, Y.; Hoffman-Censits, J.; Perez-Gracia, J.L.; Petrylak, D.P.; Derleth, C.L.; Tayama, D.; Zhu, Q.; Ding, B.; et al. Atezolizumab in platinum-treated locally advanced or metastatic urothelial carcinoma: Post-progression outcomes from the phase II IMvigor210 study. Ann. Oncol. 2017, 28, 3044-3050. [CrossRef]

38. Schmid, P.; Rugo, H.S.; Adams, S.; Schneeweiss, A.; Barrios, C.H.; Iwata, H.; Diéras, V.; Henschel, V.; Molinero, L.; Chui, S.Y.; et al. Atezolizumab plus nab-paclitaxel as first-line treatment for unresectable, locally advanced or metastatic triple-negative breast cancer (IMpassion130): Updated efficacy results from a randomised, double-blind, placebo-controlled, phase 3 trial. Lancet Oncol. 2020, 21, 44-59. [CrossRef]

39. Migden, M.R.; Rischin, D.; Schmults, C.D.; Guminski, A.; Hauschild, A.; Lewis, K.D.; Chung, C.H.; Hernandez-Aya, L.; Lim, A.M.; Chang, A.L.S.; et al. PD-1 blockade with cemiplimab in advanced cutaneous squamous-cell carcinoma. N. Engl. J. Med. 2018, 379, 341-351. [CrossRef]

40. Tan, S.; Liu, K.; Chai, Y.; Zhang, C.W.H.; Gao, S.; Gao, G.F.; Qi, J. Distinct PD-L1 binding characteristics of therapeutic monoclonal antibody durvalumab. Protein Cell 2018, 9, 135-139. [CrossRef]

41. Garassino, M.C.; Cho, B.C.; Kim, J.H.; Mazières, J.; Vansteenkiste, J.; Lena, H.; Corral Jaime, J.; Gray, J.E.; Powderly, J.; Chouaid, C.; et al. Durvalumab as third-line or later treatment for advanced non-small-cell lung cancer (ATLANTIC): An open-label, single-arm, phase 2 study. Lancet Oncol. 2018, 19, 521-536. [CrossRef]

42. Massard, C.; Gordon, M.S.; Sharma, S.; Rafii, S.; Wainberg, Z.A.; Luke, J.; Curiel, T.J.; Colon-Otero, G.; Hamid, O.; Sanborn, R.E.; et al. Safety and efficacy of durvalumab (MEDI4736), an anti-programmed cell death ligand-1 immune checkpoint inhibitor, in patients with advanced urothelial bladder cancer. J. Clin. Oncol. 2016, 34, 3119-3125. [CrossRef]

43. Study of Azacitidine in Combination with Pembrolizumab in Relapsed/Refractory Acute Myeloid Leukemia (AML) Patients and in Newly Diagnosed Older ( $\geq 65$ Years) AML Patients. Available online: https: / clinicaltrials.gov/ct2 / show / NCT02845297? term=pembrolizumab\&cond=Acute + Myeloid + Leukemia\&draw=2\&rank=1 (accessed on 30 October 2020).

44. Loibl, S.; Untch, M.; Burchardi, N.; Huober, J.B.; Blohmer, J.U.; Grischke, E.-M.; Furlanetto, J.; Tesch, H.; Hanusch, C.; Rezai, M.; et al. A randomized phase II neoadjuvant study (GeparNuevo) to investigate the addition of durvalumab, a PD-L1 antibody, to a taxane-anthracycline containing chemotherapy in triple negative breast cancer (TNBC). J. Clin. Oncol. 2017, 35, 3062. [CrossRef]

45. Lee, J.Y.; Kim, J.W.; Lim, M.C.; Kim, S.; Kim, H.S.; Choi, C.H.; Yi, J.Y.; Park, S.Y.; Kim, B.G. A phase II study of neoadjuvant chemotherapy plus durvalumab and tremelimumab in advanced-stage ovarian cancer: A Korean gynecologic oncology group study (KGOG 3046), TRU-D. J. Gynecol. Oncol. 2019, 30, 1-8. [CrossRef]

46. Lee, J.M.; Cimino-Mathews, A.; Peer, C.J.; Zimmer, A.; Lipkowitz, S.; Annunziata, C.M.; Cao, L.; Harrell, M.I.; Swisher, E.M.; Houston, N.; et al. Safety \& clinical activity of the programmed death-ligand 1 inhibitor durvalumab in combination with Poly (ADP-Ribose) polymerase inhibitor olaparib or vascular endothelial growth factor Receptor 1-3 Inhibitor Cediranib in Women's Cancers: A dose-escalati. J. Clin. Oncol. 2017, 35, 2193-2202. [CrossRef] [PubMed]

47. Boyerinas, B.; Jochems, C.; Fantini, M.; Heery, C.R.; Gulley, J.L.; Tsang, K.Y.; Schlom, J. Antibody-dependent cellular cytotoxicity activity of a Novel Anti-PD-L1 antibody avelumab (MSB0010718C) on human tumor cells. Cancer Immunol. Res. 2015, 3, 1148-1157. [CrossRef] [PubMed] 
48. D’Angelo, S.P.; Russell, J.; Lebbé, C.; Chmielowski, B.; Gambichler, T.; Grob, J.J.; Kiecker, F.; Rabinowits, G.; Terheyden, P.; Zwiener, I.; et al. Efficacy and safety of first-line avelumab treatment in patients with stage IV metastatic merkel cell carcinoma a preplanned interim analysis of a clinical trial. JAMA Oncol. 2018, 4, 1-5. [CrossRef] [PubMed]

49. Hassan, R.; Thomas, A.; Patel, M.R.; Nemunaitis, J.J.; Bennouna, J.; Powderly, J.D.; Taylor, M.H.; Dowlati, A.; Chen, F.; Leach, J.; et al. Avelumab (MSB0010718C; anti-PD-L1) in patients with advanced unresectable mesothelioma from the JAVELIN solid tumor phase Ib trial: Safety, clinical activity, and PD-L1 expression. J. Clin. Oncol. 2016, 34, 8503. [CrossRef]

50. Disis, M.L.; Patel, M.R.; Pant, S.; Infante, J.R.; Lockhart, A.C.; Kelly, K.; Beck, J.T.; Gordon, M.S.; Weiss, G.J.; Ejadi, S.; et al. Avelumab (MSB0010718C), an anti-PD-L1 antibody, in patients with previously treated, recurrent or refractory ovarian cancer: A phase Ib, open-label expansion trial. J. Clin. Oncol. 2015, 33, 5509. [CrossRef]

51. Gulley, J.L.; Spigel, D.; Kelly, K.; Chandler, J.C.; Rajan, A.; Hassan, R.; Wong, D.J.L.; Leach, J.; Edenfield, W.J.; Wang, D.; et al. Avelumab (MSB0010718C), an anti-PD-L1 antibody, in advanced NSCLC patients: A phase 1b, open-label expansion trial in patients progressing after platinum-based chemotherapy. J. Clin. Oncol. 2015, 33, 8034. [CrossRef]

52. Chung, H.C.; Arkenau, H.-T.; Wyrwicz, L.; Oh, D.-Y.; Lee, K.-W.; Infante, J.R.; Lee, S.S.; Lee, J.; Keilholz, U.; Mita, A.C.; et al. Avelumab (MSB0010718C; anti-PD-L1) in patients with advanced gastric or gastroesophageal junction cancer from JAVELIN solid tumor phase Ib trial: Analysis of safety and clinical activity. J. Clin. Oncol. 2016, 34, 4009. [CrossRef]

53. Apolo, A.B.; Infante, J.R.; Balmanoukian, A.; Patel, M.R.; Wang, D.; Kelly, K.; Mega, A.E.; Britten, C.D.; Ravaud, A.; Mita, A.C.; et al. Avelumab, an anti-programmed death-ligand 1 antibody, in patients with refractory metastatic urothelial carcinoma: Results from a multicenter, Phase Ib study. J. Clin. Oncol. 2017, 35, 2117-2124. [CrossRef]

54. Kuo, C.H.; Hsieh, T.C.; Wang, C.H.; Chou, C.L.; Lai, Y.H.; Chen, Y.Y.; Lin, Y.L.; Wu, S.T.; Fang, T.C. Increased risks of mortality and atherosclerotic complications in incident hemodialysis patients subsequently with bone fractures: A nationwide case-matched cohort study. PLoS ONE 2015, 10, e0121705. [CrossRef]

55. Lin, C.C.; Taylor, M.; Boni, V.; Brunsvig, P.F.; Geater, S.L.; Salvagni, S.; Garrido Lopez, P.; Özgüroğlu, M.; Sriuranpong, V.; Ponce Aix, S.; et al. Phase I/II study of spartalizumab (PDR001), an anti-PD1 mAb, in patients with advanced melanoma or non-small cell lung cancer. Ann. Oncol. 2018, 29, viii413. [CrossRef]

56. Naing, A.; Gainor, J.F.; Gelderblom, H.; Forde, P.M.; Butler, M.O.; Lin, C.C.; Sharma, S.; Ochoa de Olza, M.; Varga, A.; Taylor, M.; et al. A first-in-human phase 1 dose escalation study of spartalizumab (PDR001), an anti-PD-1 antibody, in patients with advanced solid tumors. J. Immunother. Cancer 2020, 8, e00530. [CrossRef] [PubMed]

57. ClinicalTrials.gov. Study of PDR001 and/or MBG453 in Combination with Decitabine in Patients with AML or High Risk MDS. Available online: https:/ / clinicaltrials.gov/ct2/show/NCT03066648 (accessed on 30 December 2020).

58. Duan, J.; Cui, L.; Zhao, X.; Bai, H.; Cai, S.; Wang, G.; Zhao, Z.; Zhao, J.; Chen, S.; Song, J.; et al. Use of Immunotherapy With Programmed Cell Death 1 vs. Programmed Cell Death Ligand 1 Inhibitors in Patients With Cancer: A Systematic Review and Meta-analysis. JAMA Oncol. 2020, 6, 375-384. [CrossRef]

59. Yarchoan, M.; Hopkins, A.; Jaffee, E.M. Tumor mutational burden and response rate to PD-1 inhibition. Massachussetts Med. Soc. 2017, 377, 2500-2501. [CrossRef]

60. Lichtman, M.A. A historical perspective on the development of the cytarabine (7 days) and daunorubicin (3 days) treatment regimen for acute myelogenous leukemia: 2013 the 40th anniversary of $7+3$. Blood Cells Mol. Dis. 2013, 50, 119-130. [CrossRef] [PubMed]

61. Bohl, S.R.; Bullinger, L.; Rücker, F.G. New targeted agents in acute myeloid leukemia: New hope on the rise. Int. J. Mol. Sci. 2019, 20, 1983. [CrossRef]

62. Kantarjian, H. Acute myeloid leukemia-Major progress over four decades and glimpses into the future. Am. J. Hematol. 2016, 91, 131-145. [CrossRef]

63. Chan, T.A.; Yarchoan, M.; Jaffee, E.; Swanton, C.; Quezada, S.A.; Stenzinger, A.; Peters, S. Development of tumor mutation burden as an immunotherapy biomarker: Utility for the oncology clinic. Ann. Oncol. 2019, 30, 44-56. [CrossRef] [PubMed]

64. Curran, E.K.; Godfrey, J.; Kline, J. Mechanisms of Immune Tolerance in Leukemia and Lymphoma. Trends Immunol. 2017, 38, 513-525. [CrossRef]

65. Younes, A.; Santoro, A.; Shipp, M.; Zinzani, P.L.; Timmerman, J.M.; Ansell, S.; Armand, P.; Fanale, M.; Ratanatharathorn, V.; Kuruvilla, J.; et al. Nivolumab for classical Hodgkin's lymphoma after failure of both autologous stem-cell transplantation and brentuximab vedotin: A multicentre, multicohort, single-arm phase 2 trial. Lancet Oncol. 2016, 17, 1283-1294. [CrossRef]

66. Chen, R.; Zinzani, P.L.; Lee, H.J.; Armand, P.; Johnson, N.A.; Brice, P.; Radford, J.; Ribrag, V.; Molin, D.; Vassilakopoulos, T.P.; et al. Pembrolizumab in relapsed or refractory Hodgkin lymphoma: 2-year follow-up of KEYNOTE-087. Blood 2019, 134, 1144-1153. [CrossRef]

67. Zhang, L.; Chen, X.; Liu, X.; Kline, D.E.; Teague, R.M.; Gajewski, T.F.; Kline, J. CD40 ligation reverses T cell tolerance in acute myeloid leukemia. J. Clin. Investig. 2013, 123, 1999-2010. [CrossRef] [PubMed]

68. Boddu, P.; Kantarjian, H.; Garcia-Manero, G.; Allison, J.; Sharma, P.; Daver, N. The emerging role of immune checkpoint based approaches in AML and MDS. Leuk. Lymphoma 2018, 59, 790-802. [CrossRef] [PubMed]

69. Ryan, M.; Teague, J.K. Immune evasion in acute myeloid leukemia: Current concepts and future directions. J. Immunother. Cancer 2013, 1, 13. [CrossRef]

70. Rashidi, A.; Fisher, S.I. Spontaneous remission of acute myeloid leukemia. Leuk. Lymphoma 2015, 56, 1727-1734. [CrossRef] [PubMed] 
71. Li, Z.; Philip, M.; Ferrell, P.B. Alterations of T-cell-mediated immunity in acute myeloid leukemia. Oncogene 2020, 39, 3611-3619. [CrossRef]

72. Wang, R.; Feng, W.; Wang, H.; Wang, L.; Yang, X.; Yang, F.; Zhang, Y.; Liu, X.; Zhang, D.; Ren, Q.; et al. Blocking migration of regulatory $\mathrm{T}$ cells to leukemic hematopoietic microenvironment delays disease progression in mouse leukemia model. Cancer Lett. 2020, 469, 151-161. [CrossRef]

73. Gutierrez, L.; Jang, M.; Zhang, T.; Akhtari, M.; Alachkar, H. Midostaurin reduces Regulatory T cells markers in Acute Myeloid Leukemia. Sci. Rep. 2018, 8, 17544. [CrossRef] [PubMed]

74. Christopher, M.J.; Petti, A.A.; Rettig, M.P.; Miller, C.A.; Chendamarai, E.; Duncavage, E.J.; Klco, J.M.; Helton, N.M.; O’Laughlin, M.; Fronick, C.C.; et al. Immune Escape of Relapsed AML Cells after Allogeneic Transplantation. N. Engl. J. Med. 2018, 379, 2330-2341. [CrossRef]

75. Jaiswal, S.; Jamieson, C.H.; Pang, W.W.; Park, C.Y.; Chao, M.P.; Majeti, R.; Traver, D.; van Rooijen, N.; Weissman, I.L. CD47 is upregulated on circulating hematopoietic stem cells and leukemia cells to avoid phagocytosis. Cell 2009, 138, 271-285. [CrossRef] [PubMed]

76. Takimoto, C.H.; Chao, M.P.; Gibbs, C.; McCamish, M.A.; Liu, J.; Chen, J.Y.; Majeti, R.; Weissman, I.L. The Macrophage 'Do not eat me' signal, CD47, is a clinically validated cancer immunotherapy target. Ann. Oncol. 2019, 30, 486-489. [CrossRef] [PubMed]

77. Sikic, B.I.; Lakhani, N.; Patnaik, A.; Shah, S.A.; Chandana, S.R.; Rasco, D.; Colevas, A.D.; O’Rourke, T.; Narayanan, S.; Papadopoulos, K.; et al. First-in-Human, First-in-Class Phase I Trial of the Anti-CD47 Antibody Hu5F9-G4 in Patients with Advanced Cancers. J. Clin. Oncol. 2019, 37, 946-953. [CrossRef]

78. Yang, H.; Bueso-Ramos, C.; Dinardo, C.; Estecio, M.R.; Davanlou, M.; Geng, Q.R.; Fang, Z.; Nguyen, M.; Pierce, S.; Wei, Y.; et al. Expression of PD-L1, PD-L2, PD-1 and CTLA4 in myelodysplastic syndromes is enhanced by treatment with hypomethylating agents. Leukemia 2014, 28, 1280-1288. [CrossRef]

79. Ørskov, A.D.; Treppendahl, M.B.; Skovbo, A.; Holm, M.S.; Friis, L.S.; Hokland, M.; Grønbæk, K. Hypomethylation and upregulation of PD-1 in T cells by azacytidine in MDS/AML patients: A rationale for combined targeting of PD-1 and DNA methylation. Oncotarget 2015, 6, 9612-9626. [CrossRef] [PubMed]

80. Sehgal, A.; Whiteside, T.L.; Boyiadzis, M. Programmed death-1 checkpoint blockade in acute myeloid leukemia. Expert Opin. Biol. Ther. 2015, 15, 1191-1203. [CrossRef]

81. DiNardo, C.D.; Jonas, B.A.; Pullarkat, V.; Thirman, M.J.; Garcia, J.S.; Wei, A.H.; Konopleva, M.; Dohner, H.; Letai, A.; Fenaux, P.; et al. Azacitidine and Venetoclax in Previously Untreated Acute Myeloid Leukemia. N. Engl. J. Med. 2020, 383, 617-629. [CrossRef] [PubMed]

82. Zeidan, A.M.; Boddu, P.; Wood, B.L.; Zelterman, D.; Little, R.F.; Ivy, S.P.; Caldwell, A.; Sanchez-Espiridion, B.; Alatrash, G.; Sharon, E.; et al. Blast MRD AML-2: Blockade of PD-1 Added to Standard Therapy to Target Measurable Residual Disease (MDR) in Acute Myeloid Leukemia (AML) 2- a Randomized Phase 2 Study of the Venetoclax, Azacitidine, and Pembrolizumab Versus Venetoclax and Azacitidine As First Line Therapy in Older Patients with AML Who Are Ineligible or Who Refuse Intensive Chemotherapy. Blood 2020, 136, 11-12. [CrossRef]

83. Daver, N.; Garcia-Manero, G.; Basu, S.; Boddu, P.C.; Alfayez, M.; Cortes, J.E.; Konopleva, M.; Ravandi-Kashani, F.; Jabbour, E.; Kadia, T.; et al. Efficacy, safety, and biomarkers of response to azacitidine and nivolumab in relapsed/ refractory acute myeloid leukemia: A nonrandomized, open-label, phase II study. Cancer Discov. 2019, 9, 370-383. [CrossRef] [PubMed]

84. Lindblad, K.E.; Thompson, J.; Gui, G.; Valdez, J.; Worthy, T.; Tekleab, H.; Hughes, T.; Goswami, M.; Oetjen, K.; Kim, D.-Y.; et al. Pembrolizumab and Decitabine for Refractory or Relapsed Acute Myeloid Leukemia. Blood 2018, 132, 1437. [CrossRef]

85. Daver, N.; Garcia-Manero, G.; Basu, S.; Cortes, J.E.; Ravandi, F.; Jabbour, E.J.; Assi, R.; Brandt, M.; Pierce, S.; Gordon, T.; et al. Nivolumab (Nivo) with Azacytidine (AZA) in Patients (pts) with Relapsed Acute Myeloid Leukemia (AML) or Frontline Elderly AML. Blood 2017, 130, 1345. [CrossRef]

86. Ravandi, F.; Assi, R.; Daver, N.; Benton, C.B.; Kadia, T.; Thompson, P.A.; Borthakur, G.; Alvarado, Y.; Jabbour, E.J.; Konopleva, M.; et al. Idarubicin, cytarabine, and nivolumab in patients with newly diagnosed acute myeloid leukaemia or high-risk myelodysplastic syndrome: A single-arm, phase 2 study. Lancet Haematol. 2019, 6, e480-e488. [CrossRef]

87. Zeidner, J.F.; Vincent, B.G.; Esparza, S.; Ivanova, A.; Moore, D.T.; Foster, M.C.; Coombs, C.C.; Jamieson, K.; Van Deventer, H.W.; Blanchard, L.; et al. Final Clinical Results of a Phase II Study of High Dose Cytarabine Followed By Pembrolizumab in Relapsed/Refractory AML. Blood 2019, 134, 831. [CrossRef]

88. BLAST MRD AML-2: BLockade of PD-1 Added to Standard Therapy to Target Measurable Residual Disease in Acute Myeloid Leukemia 2- A Randomized Phase 2 Study of Anti-PD-1 Pembrolizumab in Combination With Azacitidine and Venetoclax as Frontline Therapy in Unfit Patients With Acute Myeloid Leukemia. Available online: https:/ / clinicaltrials.gov/ct2/show /NCT0 4284787?term=pembrolizumab\&cond=Acute+Myeloid+Leukemia\&draw=2\&rank=4 (accessed on 30 October 2020).

89. BLAST MRD AML-1: BLockade of PD-1 Added to Standard Therapy to Target Measurable Residual Disease in Acute Myeloid Leukemia 1- A Randomized Phase 2 Study of Anti-PD-1 Pembrolizumab in Combination with Intensive Chemotherapy as Frontline Therapy in Patients With Acute Myeloid Leukemia. Available online: https://clinicaltrials.gov/ct2/show/record/ NCT04214249? term=pembrolizumab\&cond=Acute+Myeloid+Leukemia\&draw=2\&rank=7 (accessed on 30 October 2020).

90. Nivolumab in Eliminating Minimal Residual Disease and Preventing Relapse in Patients With Acute Myeloid Leukemia in Remission After Chemotherapy—Full Text View_ClinicalTrials.gov. Available online: https://clinicaltrials.gov/ct2/show / NCT02275533?term=nivolumab\&cond=Acute+Myeloid+Leukemia\&draw=2\&rank=2 (accessed on 30 October 2020). 
91. Liao, D.; Wang, M.; Liao, Y.; Li, J.; Niu, T. A Review of Efficacy and Safety of Checkpoint Inhibitor for the Treatment of Acute Myeloid Leukemia. Front. Pharm. 2019, 10, 609. [CrossRef]

92. Kline, J.; Liu, H.; Michael, T.; Artz, A.S.; Godfrey, J.; Curran, E.K.; Stock, W.; Smith, S.M.; Bishop, M.R. Pembrolizumab for the Treatment of Disease Relapse Following Allogeneic Hematopoietic Cell Transplantation. Blood 2018, 132, 3415. [CrossRef]

93. Ijaz, A.; Khan, A.Y.; Malik, S.U.; Faridi, W.; Fraz, M.A.; Usman, M.; Tariq, M.J.; Durer, S.; Durer, C.; Russ, A.; et al. Significant Risk of Graft-versus-Host Disease with Exposure to Checkpoint Inhibitors before and after Allogeneic Transplantation. Biol. Blood Marrow Transplant. 2019, 25, 94-99. [CrossRef] [PubMed]

94. Haverkos, B.M.; Abbott, D.; Hamadani, M.; Armand, P.; Flowers, M.E.; Merryman, R.; Kamdar, M.; Kanate, A.S.; Saad, A.; Mehta, A.; et al. PD-1 blockade for relapsed lymphoma post-allogeneic hematopoietic cell transplant: High response rate but frequent GVHD. Blood 2017, 130, 221-228. [CrossRef]

95. Godfrey, J.; Bishop, M.R.; Syed, S.; Hyjek, E.; Kline, J. PD-1 blockade induces remissions in relapsed classical Hodgkin lymphoma following allogeneic hematopoietic stem cell transplantation. J. Immunother. Cancer 2017, 5, 11. [CrossRef]

96. Albring, J.C.; Inselmann, S.; Sauer, T.; Schliemann, C.; Altvater, B.; Kailayangiri, S.; Rossig, C.; Hartmann, W.; Knorrenschild, J.R.; Sohlbach, K.; et al. PD-1 checkpoint blockade in patients with relapsed AML after allogeneic stem cell transplantation. Bone Marrow Transpl. 2017, 52, 317-320. [CrossRef]

97. Oran, B.; Garcia-Manero, G.; Saliba, R.M.; Alfayez, M.; Al-Atrash, G.; Ciurea, S.O.; Jabbour, E.J.; Mehta, R.S.; Popat, U.R.; Ravandi, F.; et al. Posttransplantation cyclophosphamide improves transplantation outcomes in patients with AML/MDS who are treated with checkpoint inhibitors. Cancer 2020, 126, 2193-2205. [CrossRef] [PubMed]

98. Rautenberg, C.; Germing, U.; Haas, R.; Kobbe, G.; Schroeder, T. Relapse of Acute Myeloid Leukemia after Allogeneic Stem Cell Transplantation: Prevention, Detection, and Treatment. Int. J. Mol. Sci. 2019, 20, 228. [CrossRef] [PubMed]

99. Köhler, N.; Ruess, D.A.; Kesselring, R.; Zeiser, R. The Role of Immune Checkpoint Molecules for Relapse After Allogeneic Hematopoietic Cell Transplantation. Front. Immunol. 2021, 12, 535. [CrossRef] [PubMed]

100. Nivolumab and Ipilimumab After Donor Stem Cell Transplant in Treating Patients with High Risk Refractory or Relapsed Acute Myeloid Leukemia or Myelodysplastic Syndrome. Available online: https:/ clinicaltrials.gov/ct2/show / NCT03600155?term= nivolumab\&cond =Acute + Myeloid + Leukemia\&draw $=2 \&$ rank $=4$ (accessed on 30 October 2020).

101. McDuffee, E.; Aue, G.; Cook, L.; Ramos-Delgado, C.; Shalabi, R.; Worthy, T.; Vo, P.; Childs, R.W. Tumor regression concomitant with steroid-refractory GvHD highlights the pitfalls of PD-1 blockade following allogeneic hematopoietic stem cell transplantation. Bone Marrow Transpl. 2017, 52, 759-761. [CrossRef] [PubMed]

102. Krönig, H.; Kremmler, L.; Haller, B.; Englert, C.; Peschel, C.; Andreesen, R.; Blank, C.U. Interferon-induced programmed death-ligand 1 (PD-L1/B7-H1) expression increases on human acute myeloid leukemia blast cells during treatment. Eur. J. Haematol. 2014, 92, 195-203. [CrossRef]

103. Berthon, C.; Driss, V.; Liu, J.; Kuranda, K.; Leleu, X.; Jouy, N.; Hetuin, D.; Quesnel, B. In acute myeloid leukemia, B7-H1 (PD-L1) protection of blasts from cytotoxic T cells is induced by TLR ligands and interferon-gamma and can be reversed using MEK inhibitors. Cancer Immunol. Immunother. 2010, 59, 1839-1849. [CrossRef]

104. Lai, C.; Vadakekolathu, J.; Reeder, S.; Church, S.E.; Hood, T.; Aldoss, I.; Godwin, J.; Wieduwilt, M.J.; Arellano, M.; Muth, J.; et al. TP53 abnormalities correlate with immune infiltration and are associated with response to flotetuzumab, an investigational immunotherapy, in acute myeloid leukemia. bioRxiv 2020, 44. [CrossRef]

105. Brodská, B.; Otevřelová, P.; Šálek, C.; Fuchs, O.; Gašová, Z.; Kuželová, K. High PD-L1 expression predicts for worse outcome of leukemia patients with concomitant NPM1 and FLT3 mutations. Int. J. Mol. Sci. 2019, 20, 2823. [CrossRef]

106. Greiner, J.; Schneider, V.; Schrezenmeier, H.; Wiesneth, M.; Bullinger, L.; Döhner, H.; Hofmann, S.; Götz, M. Expression of PD-L1 in Leukemic Progenitor Cells Defines NPM1 Mutated AML as a Potential Subgroup for PD1/PD-L1 Directed Immunotherapy. Blood 2018, 132, 2734. [CrossRef]

107. Testing Nivolumab in Combination with Decitabine and Venetoclax in Patients with Newly Diagnosed TP53 Gene Mutated Acute Myeloid Leukemia. Available online: https: / clinicaltrials.gov/ct2/show /NCT04277442?term=nivolumab\&cond=Acute+ Myeloid+Leukemia\&draw=2\&rank=1 (accessed on 30 October 2020).

108. Study of Idarubicin, Cytarabine, and Nivolumab in Patients with High-Risk Myelodysplastic Syndrome (MDS) and Acute Myeloid Leukemia (AML)—Full Text View_ClinicalTrials.gov. Available online: https://clinicaltrials.gov/ct2/show/NCT02464 657?term=nivolumab\&cond=Acute+Myeloid+Leukemia\&draw=2\&rank=3 (accessed on 30 October 2020).

109. Haploidentical Lymphocytes with Nivolumab/Ara-C as Consolidation in Elderly AML Patients-Full Text ViewClinicalTrials.gov. Available online: https://clinicaltrials.gov/ct2/show/NCT03381118?term=nivolumab\&cond=Acute+ Myeloid+Leukemia\&draw=2\&rank=5 (accessed on 30 October 2020).

110. Nivolumab and Azacitidine with or without Ipilimumab in Treating Patients with Refractory/Relapsed or Newly Diagnosed Acute Myeloid Leukemia. Available online: https:/ / clinicaltrials.gov/ct2/show / NCT02397720 (accessed on 30 October 2020).

111. Nivolumab in AML in Remission at High Risk for Relapse-Full Text View-ClinicalTrials.gov. Available online: https:// clinicaltrials.gov / ct2/show / NCT02532231?term=nivolumab\&cond=Acute+Myeloid+Leukemia\&draw=2\&rank=9 (accessed on 30 October 2020).

112. A Study of the IDH1 Inhibitor AG-120 in Combination with the Checkpoint Blockade Inhibitor, Nivolumab, for Patients with IDH1 Mutated Relapsed/Refractory AML and High Risk MDS. Available online: https:/ / www.clinicaltrials.gov/ct2/results? cond=aml\&term=ivosidenib+nivolumab\&cntry=\&state=\&city=\&dist= (accessed on 23 January 2021). 
113. Single Agent and Combined Inhibition after Allogeneic Stem Cell Transplant. Available online: https:/ / clinicaltrials.gov/ct2 / show /NCT02846376?term=nivolumab\&cond=Acute+Myeloid+Leukemia\&draw=3\&rank=11 (accessed on 30 October 2020).

114. DEC-205/NY-ESO-1 Fusion Protein CDX-1401, Poly ICLC, Decitabine, and Nivolumab in Treating Patients with Myelodysplastic Syndrome or Acute Myeloid Leukemia. Available online: https:/ clinicaltrials.gov / ct2/show / NCT03358719?term=nivolumab\& cond=Acute + Myeloid + Leukemia\&draw=3\&rank=12 (accessed on 30 October 2020).

115. Ipilimumab or Nivolumab in Treating Patients with Relapsed Hematologic Malignancies after Donor Stem Cell Transplant. Available online: https://clinicaltrials.gov/ct2/show /NCT01822509?term=nivolumab\&cond=Acute+Myeloid+Leukemia\& draw=3\&rank=15 (accessed on 30 October 2020).

116. Tapan Kadia, H.K.; Elias, J.; Farhad, R.; Naval, D.; Priscilla, C.; Mark, B.; Marina, K.; Jorge, C. Nivolumab maintenance therapy for patients with high-risk acute myeloid leukemia (AML) in remission. In Proceedings of the EHA22, Amsterdam, The Netherland, 23 June 2017.

117. Wei, A.H.; Fong, C.Y.; Montesinos, P.; Calbacho, M.; Gil, J.S.; Perez De Oteyza, J.; Rowe, J.M.; Wolach, O.; Ofran, Y.; Moshe, Y.; et al. A Phase 1 Study of Flotetuzumab, a CD123 x CD3 DART ${ }^{\circledR}$ Protein, Combined with MGA012, an Anti-PD-1 Antibody, in Patients with Relapsed or Refractory Acute Myeloid Leukemia. Blood 2019, 134, 2662. [CrossRef]

118. A Study Evaluating the Safety and Pharmacokinetics of Atezolizumab Administered in Combination with Hu5F9-G4 to Patients with Relapsed and/or Refractory Acute Myeloid Leukemia. Available online: https:/ clinicaltrials.gov/ct2/show/NCT0392247 7?term=atezolizumab\&cond=Acute+Myeloid+Leukemia\&draw=2\&rank=1 (accessed on 30 October 2020).

119. A Study Evaluating the Safety and Pharmacology of Atezolizumab Administered in Combination with Immunomodulatory Agents in Participants with Acute Myeloid Leukemia (AML). Available online: https://clinicaltrials.gov/ct2/show/NCT0289231 8?term=atezolizumab\&cond=Acute+Myeloid+Leukemia\&draw=2\&rank=2 (accessed on 30 October 2020).

120. A Phase Ib/II, Multicenter, Single Arm, Open-Label Study, To Evaluate the Safety, Tolerability and Efficacy of the BL-8040 and Atezolizumab Combination for Maintenance Treatment in Subjects with Acute Myeloid Leukemia Who Are 60 Years or Older-The BATTLE Study. Available online: https: / / clinicaltrials.gov / ct2/show / NCT03154827?term=atezolizumab\&cond= Acute+Myeloid+Leukemia\&draw=2\&rank=3 (accessed on 30 October 2020).

121. A Study of ASP2215 (Gilteritinib) Combined with Atezolizumab in Patients with Relapsed or Treatment Refractory FMS-like Tyrosine Kinase (FLT3) Mutated Acute Myeloid Leukemia (AML). Available online: https: / clinicaltrials.gov/ct2/show / NCT0 3730012?term=atezolizumab\&cond=Acute+Myeloid+Leukemia\&draw=2\&rank=4 (accessed on 30 October 2020).

122. Augmentation of the Graft vs. Leukemia Effect via Checkpoint Blockade with Pembrolizumab. Available online: https: / / clinicaltrials.gov/ct2/show / NCT03286114?term =NCT03286114\&draw=2\&rank=1 (accessed on 30 October 2020).

123. Zheng, H.; Mineishi, S.; Claxton, D.F.; Zhu, J.; Zhao, C.; Jia, B.; Ehmann, W.C.; Naik, S.; Songdej, N.; Hohl, R.J. Effect of Avelumab to Immune Response in AML: A Phase I Study of Avelumab in Combination with Decitabine As First Line Treatment of Unfit Patients. Blood 2019, 134, 3939. [CrossRef]

124. Avelumab and Azacitidine in Treating Patients with Refractory or Relapsed Acute Myeloid Leukemia. Available online: https: / / www.clinicaltrials.gov/ct2/show / study / NCT02953561?term=avelumab+azacitidine\&cond=aml\&draw=2\&rank=2 (accessed on 23 January 2021).

125. An Efficacy and Safety Study of Azacitidine Subcutaneous in Combination with Durvalumab (MEDI4736) in Previously Untreated Subjects with Higher-Risk Myelodysplastic Syndromes (MDS) or in Elderly Subjects with Acute Myeloid Leukemia (AML). Available online: https: / clinicaltrials.gov / ct2/show / NCT02775903 (accessed on 30 October 2020).

126. A Phase II Study of Pembrolizumab as Post-Remission Treatment of Patients $\geq 60$ with AML. Available online: https:// clinicaltrials.gov / ct2/show $/$ NCT02708641?term =pembrolizumab\&cond=Acute+Myeloid+Leukemia\&draw=2\&rank=5 (accessed on 30 October 2020).

127. High Dose Cytarabine Followed by Pembrolizumab in Relapsed/Refractory AML. Available online: https:/ / clinicaltrials.gov/ct2 / show / NCT02768792?term=pembrolizumab\&cond=Acute+Myeloid+Leukemia\&draw=2\&rank=6 (accessed on 30 October 2020).

128. Pembrolizumab and Decitabine in Treating Patients with Acute Myeloid Leukemia or Myelodysplastic Syndrome That Is Newly-Diagnosed, Recurrent, or Refractory. Available online: https://clinicaltrials.gov/ct2/show /NCT03969446?term= pembrolizumab\&cond=Acute+Myeloid +Leukemia\&draw=2\&rank=8 (accessed on 30 October 2020).

129. MRD-Guided Treatment in NPM1mut AML Patients. Available online: https://clinicaltrials.gov/ct2/show/study/NCT0376953 2? term =pembrolizumab\&cond=Acute + Myeloid + Leukemia\&draw=2\&rank=9 (accessed on 30 October 2020).

130. Lymphodepletion and Anti-PD-1 Blockade to Reduce Relapse in AML Patient Not Eligible for Transplant. Available online: https: / / clinicaltrials.gov/ct2/show / NCT02771197?term=pembrolizumab\&cond=Acute+Myeloid+Leukemia\&draw=2\&rank=10 (accessed on 30 October 2020).

131. Pilot Study of Pembrolizumab Treatment for Disease Relapse after Allogeneic Stem Cell Transplantation. Available online: https: / / clinicaltrials.gov/ct2/show / NCT02981914?term=pembrolizumab\&cond=Acute+Myeloid+Leukemia\&draw=3\&rank=13 (accessed on 30 October 2020).

132. Spiers, L.; Coupe, N.; Payne, M. Toxicities associated with checkpoint inhibitors-An overview. Rheumatology 2019, 58, vii7-vii16. [CrossRef]

133. Naidoo, J.; Wang, X.; Woo, K.M.; Iyriboz, T.; Halpenny, D.; Cunningham, J.; Chaft, J.E.; Segal, N.H.; Callahan, M.K.; Lesokhin, A.M.; et al. Pneumonitis in Patients Treated With Anti-Programmed Death-1/Programmed Death Ligand 1 Therapy. J. Clin. Oncol. 2017, 35, 709-717. [CrossRef] [PubMed] 
134. Wang, D.Y.; Johnson, D.B.; Davis, E.J. Toxicities Associated With PD-1/PD-L1 Blockade. Cancer J. 2018, 24, 36-40. [CrossRef] [PubMed]

135. Robert, C.; Ribas, A.; Wolchok, J.D.; Hodi, F.S.; Hamid, O.; Kefford, R.; Weber, J.S.; Joshua, A.M.; Hwu, W.-J.; Gangadhar, T.C.; et al. Anti-programmed-death-receptor-1 treatment with pembrolizumab in ipilimumab-refractory advanced melanoma: A randomised dose-comparison cohort of a phase 1 trial. Lancet 2014, 384, 1109-1117. [CrossRef]

136. Naidoo, J.; Page, D.B.; Li, B.T.; Connell, L.C.; Schindler, K.; Lacouture, M.E.; Postow, M.A.; Wolchok, J.D. Toxicities of the anti-PD-1 and anti-PD-L1 immune checkpoint antibodies. Ann. Oncol. 2015, 26, 2375-2391. [CrossRef]

137. Byun, D.J.; Wolchok, J.D.; Rosenberg, L.M.; Girotra, M. Cancer immunotherapy-Immune checkpoint blockade and associated endocrinopathies. Nat. Rev. Endocrinol. 2017, 13, 195-207. [CrossRef] [PubMed]

138. Diem, S.; Keller, F.; Ruesch, R.; Maillard, S.A.; Speiser, D.E.; Dummer, R.; Siano, M.; Urner-Bloch, U.; Goldinger, S.M.; Flatz, L. Pembrolizumab-triggered Uveitis: An Additional Surrogate Marker for Responders in Melanoma Immunotherapy? J. Immunother. 2016, 39, 379-382. [CrossRef]

139. Hottinger, A.F. Neurologic complications of immune checkpoint inhibitors. Curr. Opin. Neurol. 2016, 29, 806-812. [CrossRef]

140. Wang, D.Y.; Okoye, G.D.; Neilan, T.G.; Johnson, D.B.; Moslehi, J.J. Cardiovascular Toxicities Associated with Cancer Immunotherapies. Curr. Cardiol. Rep. 2017, 19, 21. [CrossRef] [PubMed]

141. Puzanov, I.; Diab, A.; Abdallah, K.; Bingham, C.O., 3rd; Brogdon, C.; Dadu, R.; Hamad, L.; Kim, S.; Lacouture, M.E.; LeBoeuf, N.R.; et al. Managing toxicities associated with immune checkpoint inhibitors: Consensus recommendations from the Society for Immunotherapy of Cancer (SITC) Toxicity Management Working Group. J. Immunother. Cancer 2017, 5, 95. [CrossRef] [PubMed] 